\title{
Kabalis Bölgesi Demirçağ Yerleşim Tipleri ve Gözetleme/Haberleşme Kaleleri
}

\author{
The Kabalis Region: Observation and Communication Forts and Settlement \\ Types in the Iron Age
}

\begin{abstract}
F. Eray DÖKÜ * İsmail BAYTAK ${ }^{* *}$

Öz: Hellenistik ve Roma dönemlerinde Kibyra'nın güçlenmesiyle Kibyratis olarak anılan bölge, antik yazarların aktarımların işaret ettiği gibi Demir Çă̆ı'nda, Lydialıları oluşturan halklardan biri olan Kaballerin egemenlikleri nedeniyle Kabalis olarak adlandırılmıştır. Bölgede, Kalkolitik Dönem’de başlayan yerleşimler geç antikçağa kadar kesintisizce sürerken, özellikle Demir Çağı'nda komşusu Milyas gibi önemli bir merkez olmuş ve kendi geleneklerinde belirgin bir kültür üretmiştir. Demir Çağı'nda yoğun olarak, yüksek dağlarla çevrelenmiş nispeten büyük ovalarda, göl kenarlarında ve dağ eteklerinde birbirine yakın dağınık ve küçük yerleşim alanları halinde izlenmektedir. Bu yerleşimlerle bağlantılı nekropolislerde ise, basit sandık mezar, kaya mezarları ve Lydia Tipi olarak adlandırdığımız tümülüs tipi yanında Milyas ve Kabalis bölgelerinin neredeyse ortak gömü geleneği olarak karşılaşılan, sayıları yüzlerle ifade edilen taş yığma tümülüslerle izlenir. Zor ve yüksek bir coğrafyada görülen bu Demir Çağ yerleşimlerini ve yol ağları, yüksek tepelerde birbirlerini gören, basit moloz taş örgü savunma duvarları içerisinde, yoğun Demir Çağ seramik buluntularıyla dönemlerini söyleyen, gözetleme ve haberleşme kaleleri ile savunulduğu ortaya çıkmıştır. Bu yerleşim ve savunma tipi, Roma Dönemi'nde ve hatta geç antikçağda da, aynı coğrafyaya, aynı şekilde yerleşen ve aynı yolları kullanan ve hatta aynı güvenlik sorunlarına benzer çözümler sunan bir biçimde, zamanı aşan bir şekilde kullanılmışlardır.
\end{abstract}

Anahtar sözcükler: Demir Çăğ, Kabalis, Lydia, Yerleşim Tipleri, Gözetleme ve Haberleşme Kaleleri

\begin{abstract}
Kibyra, as indicated by the surviving quotations of ancient writers, was called Kabalis due to the Kabals' sovereignty in the Iron Age, as one of the peoples forming "the Lydians". Settlements that began to form in the Chalcolithic Period continued into Late Antiquity and together this region became an important centre, especially in the Iron Age, like neighbouring Milyas, and produced a distinct culture with its traditions. It is observed that in the Iron Age there was density of settlement on relatively large plains surrounded by high mountains, with scattered and small residential areas close to each other at lake edges and by mountain slopes. Linked to these settlements, in their necropolises we found a hundred cobbled massive tumuli, examples of a shared burial tradition in the Milyas and Kabalis regions, in addition to the simple chest grave, rock-cut tombs and also the tumulus type termed Lydian. These Iron Age settlements and road networks, which are situated in a testing geographical area, at high altitude, have been found to have been defended by a system of observation and communication points, associated with Iron Age ceramic finds and simple rubble-stone defensive walls, facing each other in line of sight on high peaks. This type of settlement and defence was also used in the Roman period and even in Late Antiquity, in a way that transcends time, employed in the same way within the same geography, using the same road routes and offering similar solutions to the same security problems.
\end{abstract}

Keywords: Iron Age, Kabalis, Lydia, Settlement types, Observation and communication forts

\footnotetext{
* Yrd. Doç. Dr., Mehmet Akif Ersoy Üniversitesi, Fen-Edebiyat Fakültesi, Arkeoloji Bölümü, Burdur. eraydoku@mehmetakif.edu.tr

${ }^{* *}$ Yrd. Doç. Dr., Dicle Üniversitesi, Edebiyat Fakültesi, Tarih Bölümü, Diyarbakır. ismail.baytak@dicle.edu.tr
} 


\section{Antik Kaynaklarda Kabalis Bölgesi}

Hellenistik ve Roma dönemlerinde Kibyra'nın güçlenmesiyle Kibyratis olarak anılan bölge, antik yazarların aktarımlarının işaret ettiği gibi Demir Çă̆ı'nda Lydialıları oluşturan halklardan biri olan Kaballerin egemenlikleri nedeniyle Kabalis olarak adlandırılmıştır (Fig. 1). İlk olarak Kabal halkının varlığına, Herodotos Historia'da (III. 90) değinir. Anadolu'da Pers egemenliği döneminde, Dareios'un satraplık düzenlemeleri içerisinde Kaballeri, ikinci satraplıkta Mysia, Lydia, Lasonia, Hytenneia yanında sayar ve beş yüz talanta gümüş ödediklerinden söz eder. Ardından, Kserkses'in Helas Seferi'nde yer alan halkları anlattığı bölümde de, Maionia'da oturan ve Lasonialı olarak çağrılan Kaballerden bahsetmiştir (Hdt. VII. 77). Maionnialılar ise Herodotos'a (I. 7; VII. 74) göre Lydialılardı ve eskiden Lydialılar, Maionialılar olarak çağrılırlard1. Dolayısıyla Maionia olarak adlandırdığı Lydia halklarından bahsederken Kaballeri de sayıyor olması oldukça önemlidir. Bütün bu anlatımlara yine Herodotos (VII. 77), Kserkses'in Hellas Seferi'nde komşuluk ilişkilerine dayanarak verdiği listede Kaballerden sonra Milyas ve Lykialılara değinmiş olması bu aktarımları daha da ilginç kılmaktadır. Böylece Herodotos, Pers döneminde Kaballerin, Lydialılar ile olan soy bağını kurarken aslında, Milyaslılar ve Lykialılar ile komşu olduğunu işaret eder. Dolayısıyla Herodotos'un aktarımlarını izleyecek olursak, Kaballerin Lydialıları oluşturan halklardan biri olması yanında, Lydia hakimiyetinin Halys'e (Kızılırmak) kadar uzandığı dönemde çokta şaşırtıcı olmayacak biçimde Milyas Bölgesi ile komşu oldukları da açıkça ortadadır.

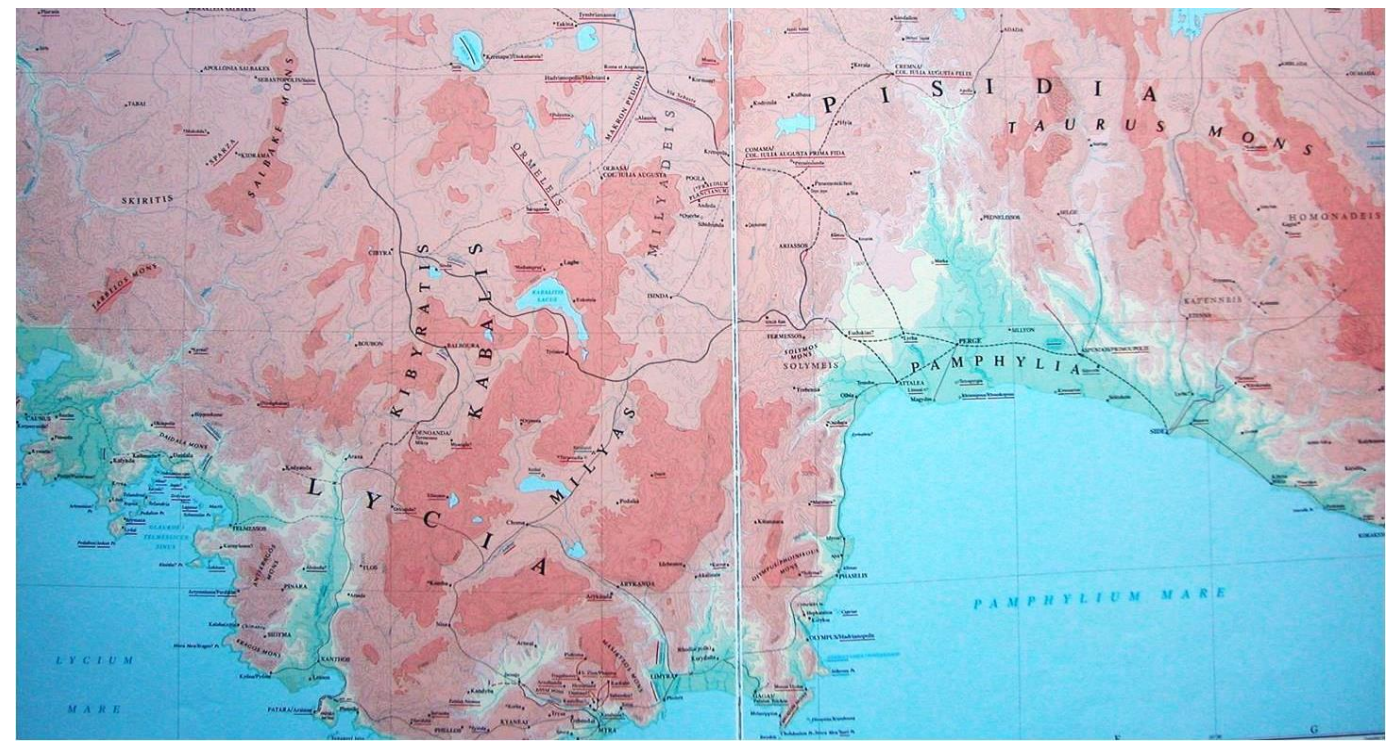

Fig. 1. Kabalis- Kibyratis Haritas1 (Barrington 2000, 65)

Ptolemaios bu durumu destekler nitelikteki aktarımında, Kabalia olarak bahsettiği bölgenin şehirlerini sayıyor olsa da, metinlerin tam olarak ele geçmemesi büyük şansızlıktır. Buna karşın alt satırında bahsettiği Milyas ile komşuluğu net bir şekilde anlaşılmaktadır.

"Kabalia'nin kentleri ise [...]

Milyas... [ $\left.\gamma_{1} \beta^{\prime}\right]$. ( $\left.\xi \beta^{\circ} L^{\prime} \lambda \zeta^{\circ} \gamma{ }_{1} \beta^{\prime}\right)$ " (Ptol. Geogr. V. 5. 6).

Yine Pers dönemi içerisinde Ksenophon'un Anabasis'inde (I. 11) aktarıldığı kadarıyla, Genç Kyros, abisi ve kral olan Artakserkses'e karşı düzenleyeceği seferin hazırlıklarını yaparken, "Kyros ayrıca kendisine ait topraklarda kargaşalık çıkardiğını söylediği Pisidialılar üzerine yürümek istediği için konuğu olan Boiotialı Proksenos'a elden geldiğince çok asker toplayıp 
yanına gelmesini rica etti" demektedir. Burada asker toplamak ve abisine karşı ayaklanmasını gizlemek için de Pisidialıları bahane etmektedir. Bu anlatımın iki önemli sonucu vardır. İlki Pisidialılar ilk defa bir antik metinde anılmıştır. İkincisi ise Pisidia'nın güneybatısında yer alan Kabalis topraklarının da Genç Kyros'a ait olduğu sonucudur. Ancak dikkat edilmesi gereken nokta, Genç Kyros'un Lydia Satrabı olmasıdır ve olasılıkla Kabalis Bölgesi Pers döneminde de Lydia ile bağını siyasi olarak sürdürmektedir.

Strabon ise Geographika'da (XIII. 4. 17) Kibyralılardan bahseden "Kibyralıların Kabalis bölgesini mesken tutan Lydialıların soyundan geldikleri söylenir. Sonradan ise kent, burayl kolonize eden sınır komşuları Pisidialıların eline geçmiş, Pisidialılar ise yerleşimi, çevresi 100 stadia uzunluğunda ve oldukça tahkimli başka bir bölgeye taşımışt. İyi yönetim (iyi kanunlar) sayesinde kent gücünü artırmış, köyleri ise Pisidia'dan ve sınır komşusu Milyas'tan Likya'ya ve Rhodos'un karşı kıyılarına kadar yayılmıştı" (Çev. Murat Arslan) der. Burada bahsettiği Lydia soylu halk Herodotos'dan bildiğimiz Kaballer olmalıdır. Ayrıca Kibyra ve çevresinde, Lydce, Solymce, Pisidce ve Hellence olmak üzere dört farklı dilin konuşulduğunu da vurgularken bir ekleme yaparak, Kibyra ve civarında "Lydce hala konuşulurken Lydia'da Lydialıların diline ait en ufak bir ipucu yoktur"der (Strab. XIII. 4. 17). Bu anlatımlar, Kabalis Bölgesi'ne ismini veren Kaballerin Lydialı olduğu ve geldikleri bu coğrafyada, Pisidialılar ve Solym halklarının yaşadığını açıkça göstermesi adına oldukça önemlidir. Ayrıca Byzantionlu Stephanos (s.v.

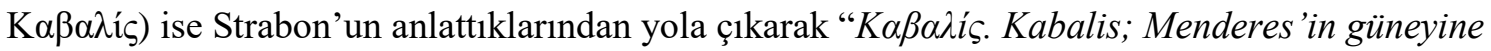
doğru, Kibyra'nın yakınındaki kent. [Strabon XIII. 4. 17] Genitivus hali Kabalidos. Vatandaşı Kabaleus (Kabalyal1). Hekataios Asya'da (olduğundan bahseder). Cinsi femininum'dur (dişidir), Strabon'un bahsedilen kitabındaki gibi (XIII. 4. 7), "Kibyralılar, Kabalia'yı iskan eden Lydialıların soyundan gelmektedir". [...]” şeklinde aktarır.

Bütün bu antik anlatımlardan, Kabalialıların, Lydialı halklardan biri olduğu, Demir Çağı'nda kendi isimlerini verdikleri Kabalia Bölgesi'nde oturdukları ve Strabon'un zamanına kadar Lydce konuştuklarını anlamak yanlış olmayacaktır.

Ancak geç dönemler için Strabon (XIII. 4. 15 c. 630) (Çev. Murat Arslan) "Karia ile Kibyrates ve Kabalis'e kadar uzanan Maiandros'un ötesinde bir bölge olan Nysa'nın arasında bulunan Mesogis'i geçtikten sonra bazı kentlere ulaşılır; Mesogis'in yakınında Laodikeia'nın karşısında, her ikisi de büyüleyici özelliğe sahip olan thermal su ve Ploutonion'un bulunduğu Hierapolis yer alır" diye aktardıktan sonra "Hierapolis'ten sonra Maiandros'un diğer tarafindaki bölümler gelir. Laodikeia, Aphrodisias ve Karura'ya kadarki bölümlerden daha önce bahsedildi. Bunlar sırasıyla; batıya doğru Maiandros üzerindeki Antiokheialıların kenti - artık Karia kenti - güneye doğru Tauros ve Likya'ya kadar uzanan Büyük Kibyra, Sinda ve Kabalis vardır" diyerek, Kabalis'i hem bir bölge hem de bir kent olarak belirtmesi oldukça ilginçtir.

Bütün bu antik kaynak verileri acaba arkeolojik buluntularla da desteklenebiliyor mu sorusu yanında, bu bölge neredeydi ve hangi alanları kapsıyordu soruları da önemli hale gelmiş bulunmaktadır.

Demir Çağı'nda Kabalis Bölgesi olarak anılan, ardından Hellenistik ve Roma dönemlerinde, Kibyra kentinin güçlenmesiyle birlikte Kibyratis olarak adlandırılan bölge, Pisidia Bölgesi'nin güney batısında, güneyde Milyas ile Lykia, doğuda Karia ve kuzeyde Phrygia ile çevrelenmiş olduğu antik kaynaklarca belirgin olsa da, tam olarak sınırlarını söyleyebilmek oldukça zordur. Kibyratis Bölgesi sınırlarını, antik kaynaklar ve arkeolojik buluntulara bakarak çizecek olursak, Hellenistik Dönem içerisinde kurulan Kibyra merkezli tetrapolis (dört kent birliği) içerisine dahil olan, Balbura, Boubon ve Oineonda'ya kadar olan bölgedir (Özüdoğru 2014, 175 vdd.). Milner ve Hall (1998, xiii) ise Kibyra'nın teritoryumu hakkında arkeolojik ve epigrafik 
delillerle, coğrafi olarak bir sınır çizer. Buna göre batıda Tefenni Ovası'nda Lysis ırmağı (Eren Çayı); kuzeyde Acıpayam, güneydoğu sınırı ise Söğüt (Karalitis - Kabalitis) Gölü olarak tanımlamıştır. Bu sınır aynı zamanda aşağıda bahsedeceğimiz ve yoğun şekilde Demir Çă̆ mezar mimarisi, seramik ve mimari kaplama levhalarının bulunduğu yerleşimleri de içine alan bir coğrafyadır.

\section{Kabalis Bölgesi Demir Çă̆ Yerleşimleri}

Bölgede yapılan yüzey araştırmalarında, Göller Yöresi Son Neolitik-Erken Kalkolitik geleneğinde Manca, Hasanpaşa, Sorkun gibi höyüklerle en erken yerleşim izleri görülmektedir. Ardından Sorkun, Manca, Çamur, Kağılcık, Küçükalan, Yusufça gibi höyüklerde Tunç Çağı'nın tüm evreleri sırasıyla izlenir. Demir Çağı yerleşimlerini tümü ise erkeninde Tunç Çağ yerleşimlerinin üzerinde boyalı seramikleriyle izlenilebilir (Baytak 2014, 99). Yapılan son çalışmalarla birlikte Uylupınar yerleşimi, Düver yerleşimi, Karamusa Höyük, Manca Höyük, Hasanpaşa Höyük ve Tavşancıl yerleşimlerinde görülen seramik buluntu, Kalkolitik ve Tunç Çağ seramiğine göre oldukça baskındır. Araştırmalarımızda bu alanlardan bulunan seramikler MÖ VII ile V. yüzyı1lar arasına tarihlendirilmiştir (Baytak 2014, 128-9) (Figs. 5, 7, 9, 11, 12, 14). Demir Çağ izleri olan tüm yerleşimlerde döneme ait farklı gömü geleneği ve mezar tiplerinden oluşan nekropolisler tespit edilmiştir. Gömü tiplerinden en dikkati çekenleriyse bölgede iki tip olarak gördüğümüz tümülüslerdir. Bunlardan ilki az sayıda olmalarına karşın, oldukça nitelikli mimarileriyle görülen Lydia tipi tümülüsler, ikincisi ise sayıları 150 ye varan yerel nitelikli taş yığma tümülüslerdir (Dökü 2015, 73-100; Dökü \& Baytak 2015). Bu ikinci tip taş yığma nekropolis alanlar Kabalis ile komşu olan, Milyas Bölgesi'nde Bayındır, Karabayır, Geçmen nekropolisleri ile oldukça yaygın olarak temsil edilirler (Dökü \& Baytak 2017, 14). Kabalis Bölgesi yerleşimlerin tümünde izlenen güçlü Orta Demir Çağ izleri, Geç Demir Çağ içerisinde yani Klasik Dönem'de bir sorunsala dönüşür. Bu sorun tüm yerleşimlerde, ithal edilen Klasik Dönem seramiğinin onlarla ifade edilen sayıca azlığıdır. Buna karşın yine bölgede Klasik Dönem'in belirteci Lykia kaya mezarlarının varlığı, yerleşimlerde bir kesintinin olmadığını göstermek için yeterli olmalıdır. Kaya mezarlarıyla tespit edilen Klasik Dönem, bu mezarlarla bağlantılı görülen yerleşimlerde bulunan az sayıda Klasik Dönem seramiği ile tezat oluşturur. $\mathrm{Bu}$ arkeolojik veri eksikliğine rağmen, özellikle Herodotos'un (III. 90) Dareios'un satraplık sistemini saydığı metinde Kaballeri, ikinci satraplıkta Mysia, Lydia, Lasonia, Hytenneia yanında sayar ve beş yüz talanta gümüş ödediklerinden söz eder. Dolayısıyla Kaballerin, Klasik Dönem'de Lykia'dan bile daha çok vergi verdiği, güçlü bir ekonomiye sahip olduğu ortadadır. Bu da, Demir Çağı'nda oluşturulan yerleşim modellerinin Klasik Dönem içinde de geleneksel olarak devam ettirildi mi sorusunu akla getirmektedir. Bölge, Demir Çăğ'ndan Hellenistik Dönem'e kadar siyasi bir birlik kuramamış, kendi geçim ekonomisi ile hayatını sürdüren yakın, dağınık ve küçük yerleşimlerinden de anlayabileceğimiz gibi şehirleşememiş olarak görünmektedir. Bu sav doğru ise, ticaretle gelen ithal bir kültürün ürünü olan Klasik Dönem seramiklerine az rastlanılması şaşırtıcı olmamalıdır. Aşağıda ayrıntılı olarak değinilecek olan Demir Çağ yerleşimleri bölgede sık, dağınık ve küçük alanlardır. Neredeyse hepsi de öncülü Tunç Çă̆ı'nı izler.

Kabalis Bölgesi Demir Çă̆ yerleşimleri, hem seramik hem de ölü gömme geleneklerinde yaratmış oldukları mimariyle rahatlıkla izlenir. Bu yerleşimler aşağıda anlatılacağı üzere birkaç tip içerisinde toplanabilmektedir. Göller ve akarsu yataklarının oluşturduğu nispeten geniş ovaların hemen yanı başında yükselen sarp dağlarla, bir kale gibi çevrelenmiş bu coğrafyada, göl ve çevresi yerleşimleri, ova yerleşimleri ve dağ eteği yamaç yerleşim tipleri izlenmektedir. 
$\mathrm{Bu}$ yerleşimleri ve yol ağlarını koruyan ve gözetleyen, ovaların hemen üzerinde yükselen dağ doruklarında, küçük boyutlu haberleşme/gözetleme kaleleriyle de çevrelenmiş olduğu arkeolojik verilerle ortaya konmuştur (Fig. 2, 15).

Göl ve Çevresi Yerleşimler: Orta Demir Çağı sonu Geç Demir Çağı başlarında, Kabalis Bölgesinde sıkça görülen göl ve göle hâkim bir tepelik ya da bir yarımada şeklindeki yerleşimler dikkat çekicidir. Şu anki bilgilerimizle bu tip yerleşimler ondan fazla höyük ile temsil edilir. Bunların en iyi örnekleri Gölhisar, Yarışlı ve Karataş Gölleri kıyı kesimlerinde ve yamaçlarında izlenir (Fig. 2, 15, 27) (Baytak 2014, 74).

Gölhisar Gölü Uylupinar (Erken Kibyra) Yerleşimi: Burdur ili Gölhisar İlçesi'nin $18 \mathrm{~km}$ güneydoğusundaki Uylupınar Gölü'nün kuzeydoğusunda, bir yarımada şeklinde görülen Göladası ya da Şehertaşı olarak tanınan alan, Uylupınar (Erken Kibyra) yerleşiminin merkezidir. Bölgede son

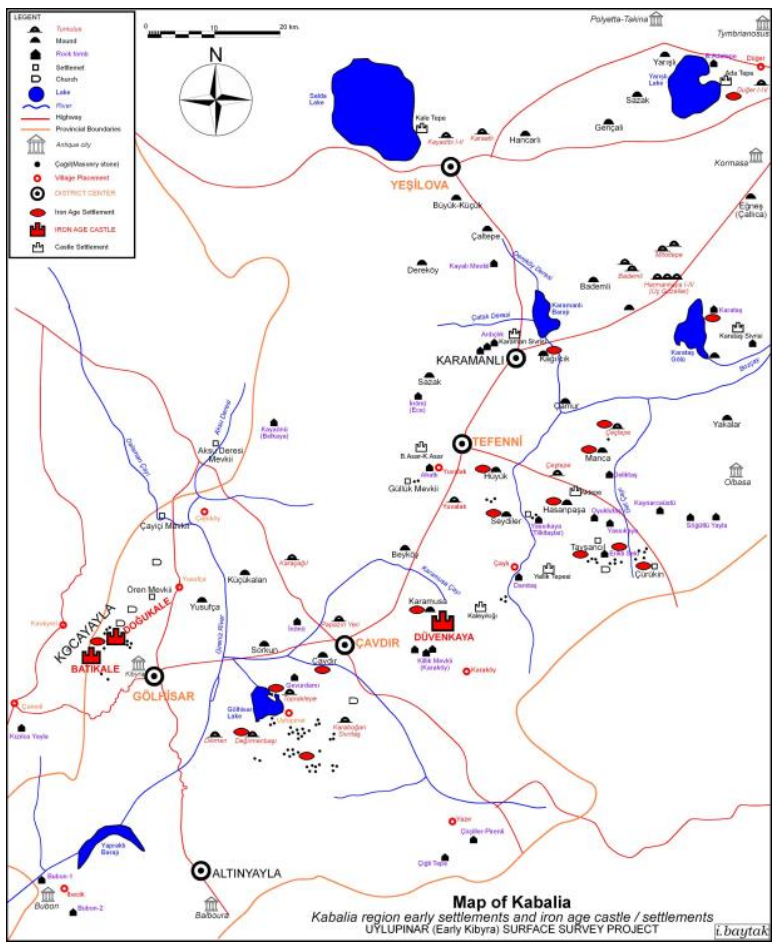

Fig. 2. Kabalis Bölgesi Kalkolitik- Demir Çă̆ Yerleşimleri. Demir Çağı Yerleşimleriyle Bağlantılı Nekropolisler ve Gözetleme/ Haberleşme Kaleleri y1llarda yoğunlaşan arkeolojik yüzey araştırmaları daha çok yerleşimin Demir Çağ’1 üzerine odaklanmıştır. İlk olarak 1975 yılında Burdur Müzesi Müdürü Kayhan Dörtlük (1975, 9-32) başkanlığında yapılan Uylupınar kurtarma kazılarında ortaya çıkan mezarlar ve buluntuları ile dikkatleri üzerine çekmiştir. Sonrasında alanda bulunan ve MÖ VIII. yüzyıl ile MÖ VI. yüzyı1 sonuna kadar inen yerel ve ithal seramikleri yayınlayan Sedef Çokay-Kepçe'nin saptamaları önemlidir (Çokay-Kepçe 2009, 29-76). Ardından, Thomas Corsten ve Oliver Hülden (2012a, 174-177) tarafından da bu alanda arkeolojik ve epigrafik çalışmalar yapılmıştır ve son olarak 2012 tarihinden itibaren Dökü ve Baytak tarafından yürütülen araştırmalar halen sürmektedir (Uylupınar (Erken Kibyra) Yüzey Araştırması Yayınları için bk. Dörtlük 1975, 9-32; Özüdoğru 2009, 419-438; Özüdoğru \& Dökü 2010; Dökü 2013, 239-249; 2014, 230-236; 2015 73-100; Dökü \& Baytak 2014, 71-89; 2015, 208-217; 2016, 217-240; 2017, 11-19; 2018, bask1da) (Fig. 3). Bu yüzey araştırmasında ekip üyesi Mehmet Kaşka $(2013,285-93)$ tarafindan Arkaik Dönem seramikleri incelenmiştir. Uylupınar yerleşim tipolojisi üzerine çalışmalar da yine araştırma ekibinde yer alan Ayça Polat-Becks (2014, 90-107) tarafından çalışılmıştır. Göladası olarak adlandırılan Şehertaşı Mevkii'nde de Son Tunç Çağı izleri görülmekte olsa da, yoğun olarak Orta Demir Çağı sonu ve Geç Demir Çağı başlarına ait buluntuları tespit edilmiştir. Özellikle göl çevresindeki yüksek tepelikler ve gölü gören yükseltilerin, bölgenin Demir Çağ ölü gömme geleneğini oluşturan 150 ye yayın taş yığma tümülüsler ve kaleler ile çevrelendiği izlenmiştir (Fig. 2).

Yarışlı Gölü Düver Yerleşimi: Düver yerleşimi de, Yarışlı Gölü kıyısında, aynı Uylupınar Yerleşimi gibi göl içine doğru giren kayalık bir yarım ada üzerindedir (Özsait 1979, 101-106, 
Lev. 53-62; Özsait 1984, 8-9; Özsait 1986b, 76-78) (Fig. 2). Özellikle yerleşimde yoğun olarak bulunmuş olan ve bugün Burdur Müzesi'nde korunan pişmiş toprak kaplama levhalarl, bölgenin Demir Çağı için oldukça önemlidir. İlk olarak Willson Cummer tarafindan çalışılan bu eserler MÖ VIII.- V. yüzyıllar arasına tarihlenirken Pisidia Bölgesinde, Phryg kültür izlerine dair en önemli veriler olarak düşünülmüştür (Cummer 1970, 29-55). Ancak Tarkan Kahya'nın yaptığı çalışmada bu eserler daha çok MÖ VI. yüzyıl sonrasına tarihlenirken, Lydia pişmiş toprak kaplama levhalarıyla yakınlık kurulur. Düver yerleşiminde bulunan bir kaya mezarının cephesine işlenen lale betimlemesi ile pişmiş toprak kaplama levhalarını bağlantılı gören Kahya, bu kaya mezarı da MÖ V. yüzyıla tarihlemiştir (Kahya 2011, 219-23; 2012a, 148-53; 2012b, 13-22). 2015 y1lında, Burdur Müzesi müdürü Ekinci

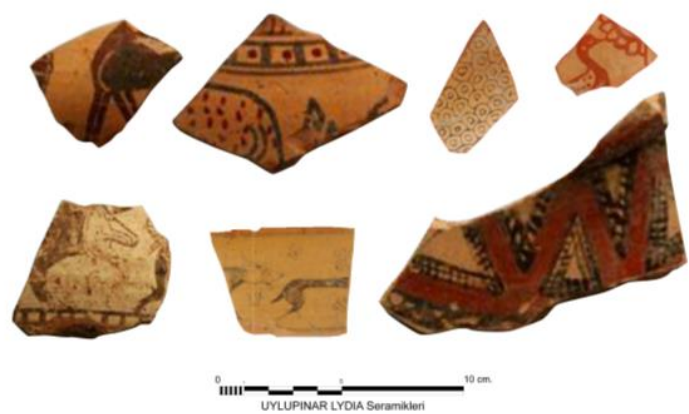

Fig. 3. Uylupınar Yerleşimi Buluntuları ve Kahya başkanlığında yürütülen kazılarda ortaya çıkarılan kaya oygu, açık hava tapınağı önünde bir taht üzerine oturan başı parçalanmış durumda bulunan Anatanrıça ve arkasındaki basamaklı sunak da Anadolu arkeolojisi için oldukça önemlidir. Kahya ve Ali Ekinci'ye (2015, 45-72) göre bu Anatanrıça tapınağı, Phryg etkisi içerisinde şekillenen Anatanrıça "Matar" inancının Lydia ve Ionia etkisiyle yapılıış bir örneğidir ve Pisidia topraklarında, MÖ VI. yüzyılın 2. yarısına tarihlenen en önemli kült alanıdır.

Karataş Gölü ve Çevresi Yerleşimleri: Karamanlı İlçe sınırlarında Karataş Gölü yamacında yapılan araştırmalarda, hem göl kıyısındaki ovada hem de gölün kenarından başlayan yüksek dağ yamaçlarında, höyükler yanında göle bakan yamaçlarda Demir Çağ yerleşimleri yoğun olarak tespit edilmiştir (Fig. 2). Tespit edilen bu höyüklerin birçoğunda Kalkolitik Dönem ile başlayan yerleşimin Tunç Çağı'nda ve sonrasında Demir Çağı'nda da devam ettiği seramik buluntuları ile ispatlanmıştır. Bu alanlarda Klasik Dönem izleri neredeyse hiç izleyemezken, Hellenistik Dönem ise az sayıda seramik buluntularla temsil edilir. En üstte ise yoğun olarak Roma Dönemi seramik buluntuları ve dağınık halde Roma Dönemi mezar tipleri izlenmiştir (Özsait 2007, 471).

Karataş Gölü'nün hemen bitiminde yer alan Küçük Karataş Sivrisi olarak da bilinen ve yamaçlarında Orta Demir Çağ sonu Geç Demir Çağ boyalı seramikleri yer aldığı gibi, aynı alanın Roma Dönemi'nde de kullanılmış olduğu arkeolojik buluntularla anlaşılmıştır (Baytak 2014, 132).

Karataş Gölü'nün güneydoğusunda yer alan Yenice Höyük etekleri kısmen sular altında kalmış olup göl çanağ içerisinde kalmaktadır. Höyük üzerinde göle bakan yamaçta Orta Demir Çağ sonu Geç Demir Çağ boyalı seramikleri izlenmiştir(Özsait 1985, 207; 1989, 4- 5, 14- 15, Lev. 3-4, 15-16). Yine Karataş Gölü yakınında Seton Lloyd ve James Mellaart tarafindan incelenmiş höyükte erken dönem malzemelerin yanı sıra benzer bir biçimde Orta Demir Çăg sonu Geç Demir Çağ boyalı seramikleri rapor edilmiştir (Lloyd \& Mellaart 1962, 196, harita 6İTÇ2; Özsait 1983, 138; 1986a, 63-6, Lev. 29-36).

\section{Ova Yerleşimleri}

Ova düzlüklerinde hafif yükselti gösteren höyük tipi yerleşimler bölgede Gölhisar, Tefenni, Karamanlı, Hasanpaşa, Acıpayam ovalarında çokça görülmektedir. Bu tip yerleşimler ova 
yüzeyinde genellikle akarsu vadilerinde yer almaktadır. Bölgede Batı Anadolu ile geçiş güzergahını sağlayan Hacılar, Kuruçay, Karaçal, Yassıgüme, Pınarbaşı, Çaltepe, Kağılcık, Çamur, Hasanpaşa, Hüyük, Beyköy, Çavdır, Sorkun, Karamusa, Küçükalan, Yusufça höyükleri siralanabilmektedir (Fig. 2).

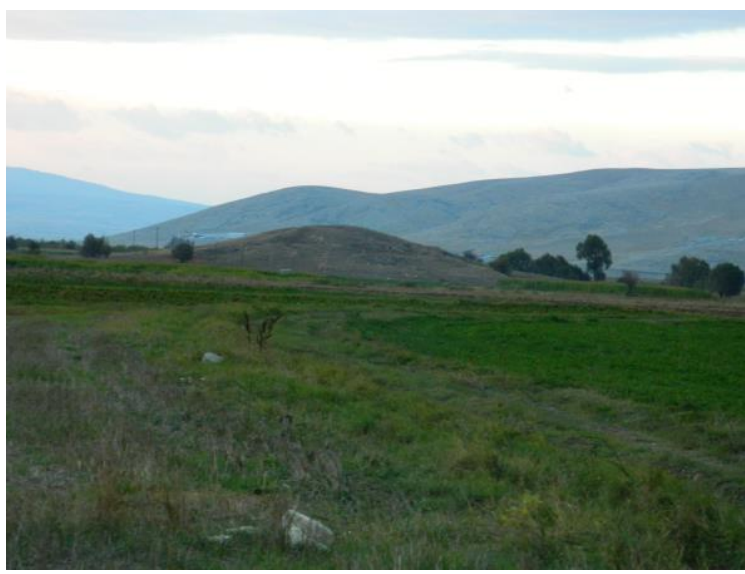

Fig. 4. Uylupınar Yerleşimi Buluntuları

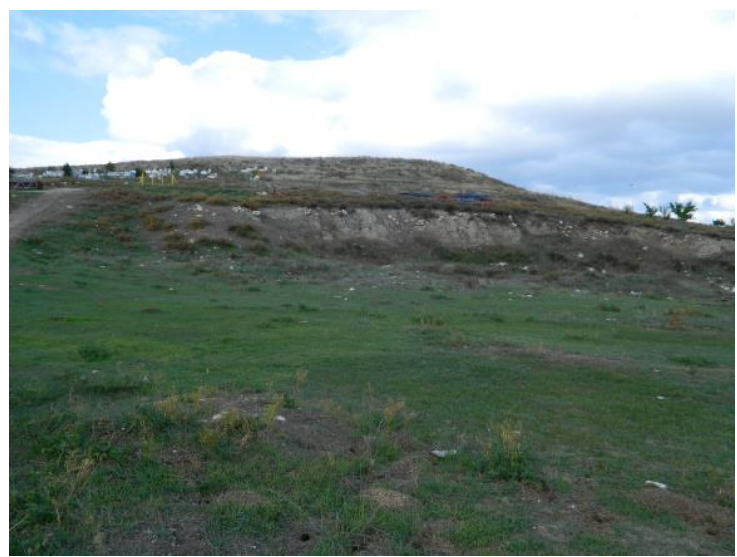

Fig. 6. Hüyük Höyük

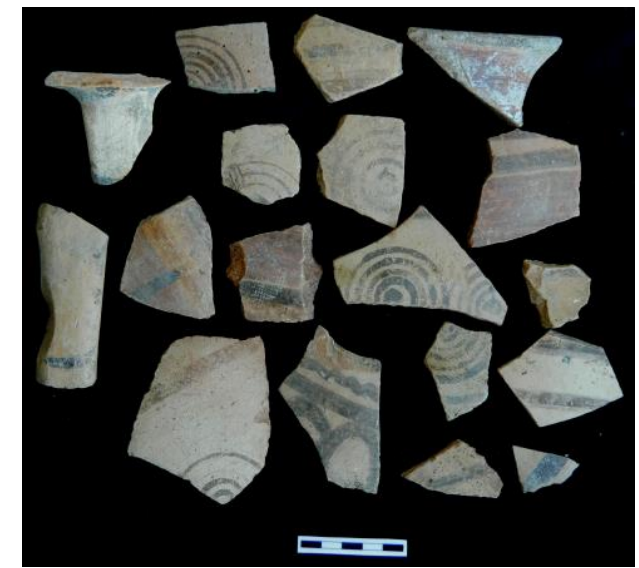

Fig. 5. Hasanpaşa Höyük Demir Çağ Seramik Buluntuları

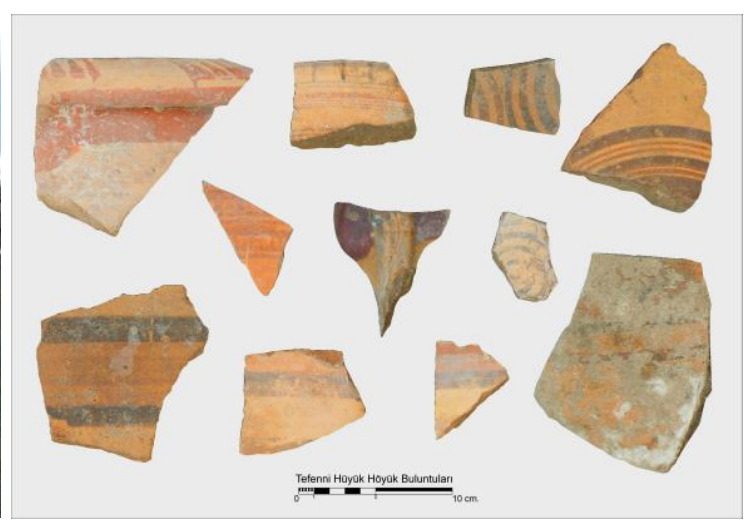

Fig. 7. Hüyük Höyük Demir Çağ Seramik Buluntuları

Burdur Karamanlı Ovası'nda araştırma yapan Özsait (1983, 137; Özsait et al. 2005, 167-189; Özsait 2006, 93-98), Karamanlı İlçesi, Kağılcık Köyü sınırlarında, Kağılcık Höyük ve köyün doğusundaki yerleşim alanlarında Orta Demir Çağ sonu Geç Demir Çağ (MÖ VII. yüzyıl-V. yüzyıl) boyalı seramikleri izlerine rastlamıştır. Yine Özsait (1977, 71-95; 1986a, 64-65) yaptığ çalışmalarda da Pınarbaşı II, Eğneş/Çallıca ve Çamur Höyük’te benzer dönem seramiklerini rapor etmiştir. Bunlara, aşağıda tanıtılacak olan Çavdır Yamaç Yerleşimi ve Karamusa Höyük de eklenebilir. Burdur-Merkez İlçe, Pınarbaşı Köyü ova kısmındaki Pınarbaşı II yerleşmesinde de yine aynı dönem kültürleri Mellaart, tarafından tespit etmiştir (Mellaart 1955, 132-136).

Hasanpaşa Höyük: Tefenni sınırları içerisinde Aşıklar Köyü sonrası Sülekler yayla yolu güzergahının başladığı yüksekçe zirvelerin hemen eteğinde oldukça verimli bir arazisi olan Hasanpaşa Mahallesi ve çevresinde araştırmalar yapılmıştır. Ova düzlügünde oldukça tahribata uğramış olan höyük malzeme olarak ise çok zengindir. Tescili yapılmış olan höyük ve çevresinde yapılan araştırmalar sonucunda Orta Demir Çağ sonu Geç Demir Çağ boyalı seramikleri yanı sıra höyükte erken dönem Son Kalkolitik - İlk Tunç Çağı seramikleri ile Roma 
Dönemi'nden de kültür izlerine rastlanılmıştır (Dökü \& Baytak, 2016, 230) (Figs. 2, 4- 5). Özellikle Demir Çağı buluntuları çevre yerleşim alanlarına göre çok iyi izlenebilmektedir. Hemen yakınındaki Hüyük Höyük ile çağdaştır (Özsait 2007, 468-469; Dökü 2014, 230-236).

Hüyük Höyük: Tefenni İlçe merkezinin 5 km kadar güneyinde Tefenni-Korkuteli yolunun hemen batı kanadında yer alan Hüyük mahallesi içerisindeki tescilli höyük bu gün köy mezarlığ olarak kullanılmaktadır. Tunç Çağ verilerinden daha baskın bir şekilde Demir Çağı seramik buluntuları oldukça dikkate değer bir şekilde izlenir (Özsait 2007, 468-470). Daha önce literatüre giren bu höyükte, İlk Tunç Çağı - Son Tunç Çağ1 - Demir Çağı ve Hellenistik Dönem seramikleri tespit edilmiş olup höyügün bir kısmı tahrip edilmiştir (Dökü \& Baytak 2016, 229) (Figs. 2, 6-7).

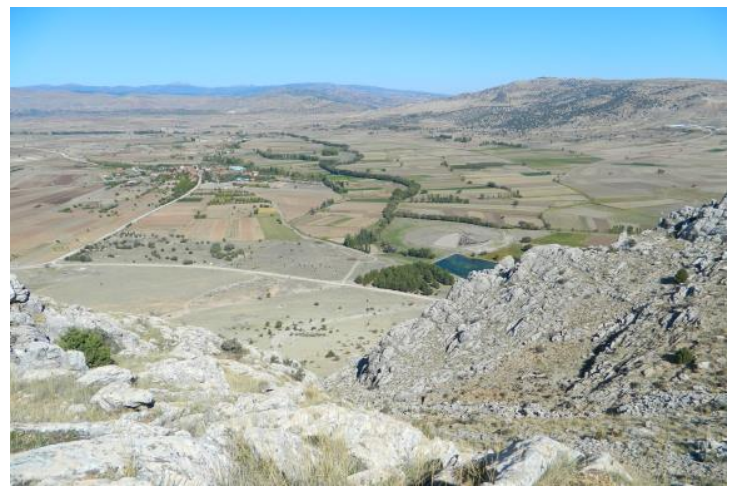

Fig. 8. Düvenkaya Gözetleme ve Haberleşme Kalesinden Karamusa Höyük

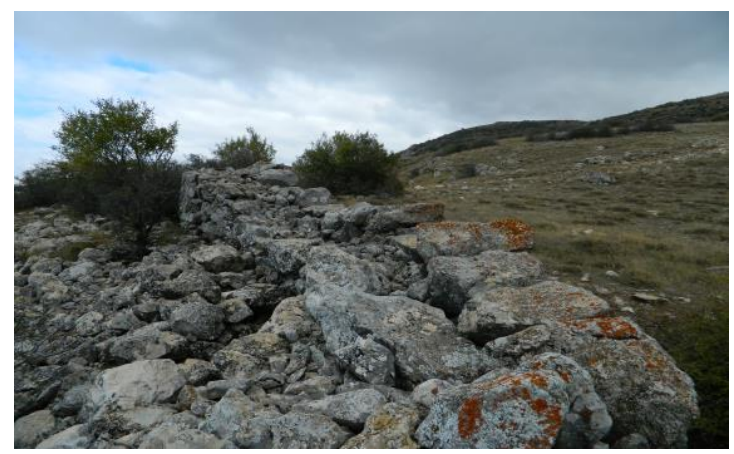

Fig. 10. Hasanpaşa Gedel Kaleyeri Sur Duvarı

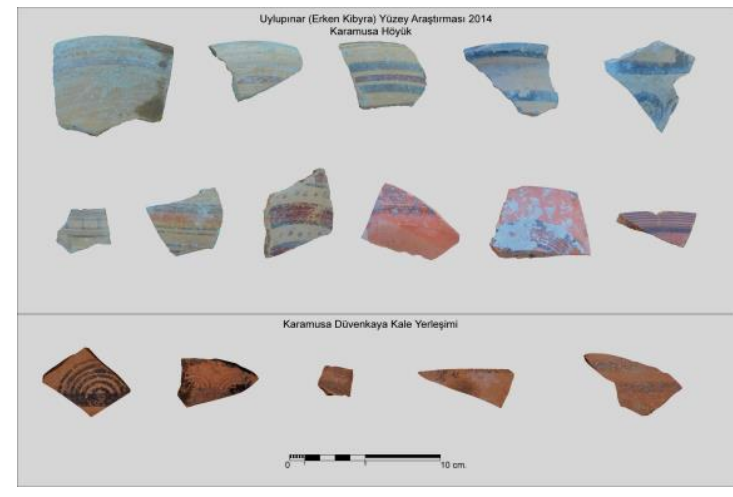

Fig. 9. Karamusa Höyük ve Düvenkayası Gözetleme ve Haberleşme Kalesi Demir Çağ Seramik Buluntuları

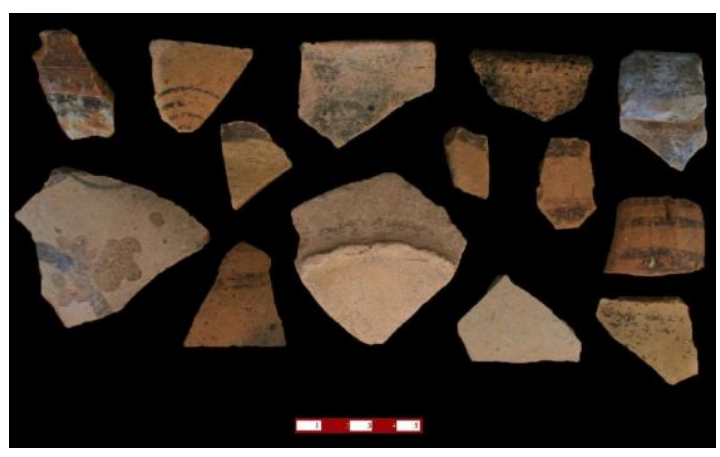

Fig. 11. Hasanpaşa, Tavşancıl-Çürükin Mevkii Demir Çağ Seramik Buluntuları

Karamusa Höyük: Tefenni ilçesi sınırlarında Tefenni Gölhisar yolunun $4 \mathrm{~km}$ kadar sol kesiminde Karamusa Köyü sınırlarında yer almaktadır. Düvenkayası zirvesinin hemen önünde konuşlanmış olup yolun altında daha önceden tescil edilmiş olan Karamusa Höyük (1215 m) köyün $1 \mathrm{~km}$ kadar güneyinde yer almaktadır (Figs. 2, 8-9). Erken dönem kültür izlerine rastlanılan Karamusa Höyük'te kaliteli Orta Demir Çağ sonu Geç Demir Çağ boyalı seramikleri oldukça yoğundur. Ayrıca bu höyükte bulunan Pişmiş toprak Kaplama levhaları Kahya'ya (2012c, 177-194) göre, özellikle MÖ VI. yüzy1l içerisinde Lydia etkilerinin bölgede görülen en belirgin arkeolojik verileridir. Höyüğün hemen karşısındaki yamaç yerleşiminde de boyalı malzeme grubunun yanı sıra Roma Dönemi seramiklerinin yanında dağınık halde Roma dönemi mezarlarına ait podyum blokları ve lahit parçaları görülmektedir. Gölet barajın hemen bitiminde 3 m'lik oldukça belirgin bir yükseltisi olan höyüğün parsellenmiş ve tarım arazisi olarak kullanılmış olduğu görülmektedir. Höyükte yapılan incelemelerde İlk Tunç Çağı - Son Tunç Çağı - 
Demir Çağı - Hellenistik ve Roma dönemleri seramikleri tespit edilmiştir (Dökü \& Baytak 2016, 230-231).

\section{Dağ Eteği Yamaç Yerleşimleri}

Dağ eteği, tepe ve yamaca konuşlandırılmış yerleşim merkezleri araziye uyum sağlanmıştır (Akarca 1972, 82). Bölgede bu sayı az olmasına rağmen birkaç örnek mevcuttur. En çarpıcı örneklerini yine Hasanpaşa sınırlarında Ayderesi ve Tavşancıl Deresi mevkiilerinde görebilmekteyiz (Baytak 2014, 74) (Fig. 2).

Tavşancıl Deresi Yerleşimi: Hasanpaşa köyü sınırlarında köyün üst kesiminde 3 km kadar batıda Tavşancıl Deresi olarak adlandırılan alanda yamaç boyunca Orta Demir Çağ sonu Geç Demir çağ boyalı seramikleri ve Roma Dönemi seramikleri yoğun olarak izlenir (Figs. 2-11). Yine oldukça geniş bir yayılım alanına sahip yerleşim $(1430 \mathrm{~m})$ ve olasılıkla Tavşancıl deresine doğru olan Gedel Mevkii güzergahında, Uylupınar ve çevresinde Demir Çağında yoğun olarak görülen taş yığma tümülüslerden oluşan bir nekropolis alanı tespit edilmiştir. Ayderesi (Özsait 2006, 98) ve Çürük İn mevkilerinde de aynı dönem kültür izleri görülebilmektedir. Böylece Demir Çağ verileri Tefenni ovası içine kadar aynı karakterde devam ettiği görülmüştür. Alanın geneline baktığımız zaman küçüklü-büyüklü 50 civarında taş yığma tümülüs izine rastlanmıştır. Yapılan incelemelerde 1490 m'de, küçük bir haberleşme/gözetleme kalesine dair taş temeller ve moloz taş duvarlar izlenmektedir (Dökü ve Baytak 2016, 230) (Fig. 10).

Yuvalak Asarova Yerleşimi: Tefenni İlçesi, Yuvalak Köyü sinırlarında Hisarova kesiminde, Büyük Asar'da Demir Çağ (Fig. 2) ve Hellenistik Dönem buluntuları, Küçük Asar'da da Demir Çağ ve Roma dönemleri buluntularının yanı sıra Geç Antik Çağ kültür izlerine de rastlanmıştır (Özsait 2007, 465). Burdur Müzesi tarafından kazılan ve Lydia Tipi Tümülüs olarak adlandırılan Yuvalak Tümülüsü ile aynı dönem buluntular vermektedir (Çankaya 2014, 246-56).

Çavdır Höyük Karşısı Yamaç Yerleşimi: Çavdır İlçesi sınırlarında, Çavdır Höyügü̈nün (Çavdır-Gölhisar yolunun güneyinde İlçe merkezinin güney batısında Çavdır mesirelik alanı olarak bilinen su kaynağı dibinde önceden tescili yapılmış İTÇ+II. bin malzemesi veren orta ölçekli bir höyük yer almaktadır) hemen $200 \mathrm{~m}$ kadar batısında oldukça geniş bir yamaç alanını kapsayan kısımda yoğun olarak Orta Demir Çağı sonu Geç Demir

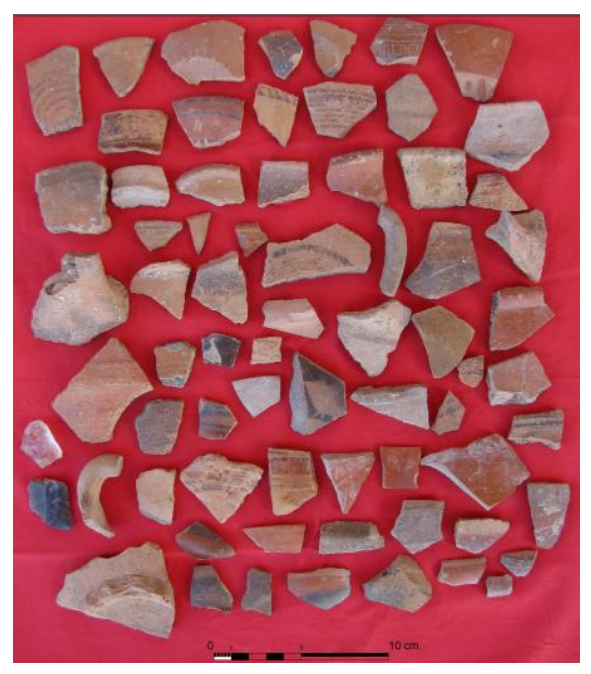

Fig. 12. Çavdır Höyük Karşısı Yamaç Yerleşimi Demir Çağ Seramik Buluntular1

Çağı boyalı seramikleri görülmüş ve hemen yakınındaki Uylupınar Şehertaşı ve Topraktepe yerleşimleriyle çağdaş olduğu anlaşılmıştır (Dökü 2014, 230-236) (Figs. 2, 12). Uylupınar yerleşimleri Demir Çağ kültürünün batı sınırı Kocayayla Batı Kale Yerleşimi ile sonlandığı görülürken aynı kültürün Çavdır boğazı ile Karamusa Höyük ile Düven Kayası güzergahıyla Tefenni ovasına doğru devam ettiği izlenmiştir. Yapılan çalışmaların sonuçlarına göre özellikle taş yığma tümülüs geleneğinin de Tefenni ve Karamanlı ovalarına kadar ulaştığı anlaşılmıştır (Dökü \& Baytak 2016, 226, 232).

Manca Höyük: Karamanlı İlçesi sınırlarında Manca (Harmankaya) Köyü içerisinde erken dönem buluntuları veren tescilli höyük yüzeyinde Orta Demir Çağı sonu Geç Demir Çağı boyalı seramikleri, yakınında yer alan Hüyük Höyük ve Hasanpaşa höyükle benzerlik gösterir (Özsait 
2007, 470; Dökü 2014, 230-236). Özsait tarafindan tespit edilen ve Manca Köyü’nün 1,5 km kadar batısında yer alan höyük, hafifçe bir yükselti halindedir. Höyük üzerinde ve çevresinde tahribat izleri mevcut olup yüzeyde Son Kalkolitik - İlk Tunç Çağı - Demir Çağı ve Roma Dönemi seramiklerine rastlanılmıştır (Figs. 13-14). Höyük yakınlarında yığma taşlar ile çevrili 10 m çapında kaçak kazı izleri görülebilen Demir Çağ ölü gömme geleneği gösteren Deliktaş Tümülüs'ü yer almaktadır. Yine buraya yakın Tefenni-Antalya karayolunun 10. km'sinde Işılar köyü yol ayrımının $500 \mathrm{~m}$ üzerinde tepelik bir yamaca konuşlanmış yığma taşlarla oluşturulmuş mezar odası duvarları (oda ölçüleri: $105 \times 70 \mathrm{~cm}$ ) belirgin tahribat görmüş olan Çeştepe Tümülüs'ü (1190 m) yer almaktadır (Dökü \& Baytak, 2016, 231-232). Ayrıca bu alandaki hakim tepenin üzerinde izlenen Manca kaya Mezarı ise Düver kaya mezarı ile birlikte bölge Demir Çağ kaya mezar geleneğini gösteren en iyi örneklerden biridir (Dökü 2015, 73-100).

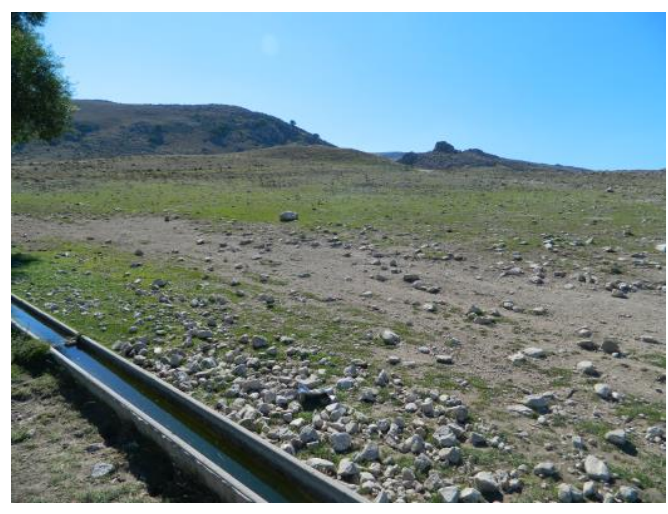

Fig. 13. Manca Höyük

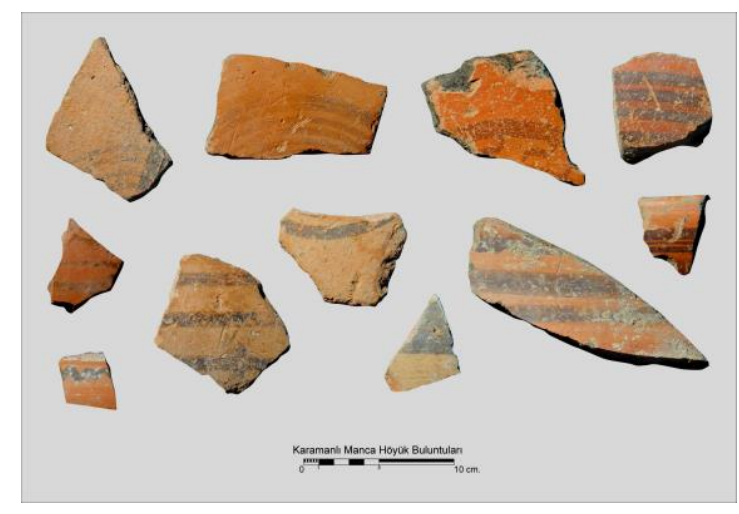

Fig. 14. Manca Höyük Demir Çağ Seramik Buluntuları

Tefenni İlçesi sınırlarında, Kayalı Köyü Beşiktepe mevkiindeki yerleşim alanı, Özsait'in Tefenni araştırmaları sırasında tespit edilmiş olup erken dönem kültürlerin yanı sıra MÖ VII.VI. yüzyıla tarihlenebilecek seramiklerin varlığından söz etmiştir. Ayrıca yine aynı alanda Kayalı II olarak adlandırdığı yerleşimde de benzer seramiklerle karşılaşmış ve iki adet tümülüs tespit edilmiştir (Özsait 1985, 389-390; Coulton 2012, 25, Fig. 11, 18).

Sonuç olarak, yukarıda değinilen ve Kalkolitik ve Tunç Çağı öncülü bulunan birçok höyükte izlenen kuvvetli Demir Çağ seramiğini ilk defa bilim dünyasına haber veren, bölgede uzun yıllardır yüzey araştırması yapan Özsait’tir. Dökü-Baytak, Kahya, Korsten, Hülden ve Coulton'un yaptıkları yüzey araştırmalarında da, Uylupınar yerleşimi, Düver yerleşimi, Karamanlı Karamusa Höyük, Manca Höyük, Hasanpaşa Höyük ve Tavşancıl yerleşimlerinde görülen seramik buluntunun Kalkolitik ve Tunç Çağ seramiğine göre baskın bir şekilde izlenen boyalı seramikleri MÖ VII-V. yüzylllar arasına tarihlenmesi önemlidir (Özsait 2006, 98). Bölgede bulunan Lydia tipi olarak adlandırabileceğimiz tümülüslerin (Çankaya 2014, 246-526) sayıca yoğunluğu ve içlerinden çıkan az sayıdaki seramik buluntunun yine MÖ VII-V. yüzyıllar olması dikkate değerdir. Diğer taraftan Kahya'nın Düver Pişmiş Toprak Kaplama Levhalarını Phrygia'dan daha çok, Lydia kültürüyle özdeşleştirmesi yanında bunların sadece Düver yerleşiminde değil Uylupınar (Corsten \& Hülden 2011, 180-183), Karamusa Höyük (Kahya 2012c, 175-194) gibi yerleşimlerde de benzer olarak tespit etmesi, diğer önemli arkeolojik verilerdendir. Dolayısıyla araştırmalar, Kabalis Bölgesi yerleşimlerinin Orta Demir Çağı sonları ve Geç Demir Çağı başlarında, kültürel birliktelikleri ortaya koymaktadır. Ayrıca bu dönemde Kabalis'in güney komşusu Milyas Bölgesi ve Lykia ile ilişkilerini en iyi anlatan arkeolojik veri ise, ölü gömme geleneklerinde her iki bölgede ortak zaman diliminde ve ortak mimarileriyle izlediğimiz taş ylğma tümülüs geleneği yanında, Kabalis Bölgesi'nin güneyinde tespit edilen 
Lykia tipi kaya mezarları ile kendini gösterir (Gay \& Corsten 2006, 47-60; Dökü 2015, 73-100).

Antik kaynakların verdiği bilgilerin, arkeolojik çalışmalarla da birebir örtüşmesi,bölgeyi daha dikkat çekici bir yer haline getirmiştir. Bu arkeolojik veriler, yukarıda bahsi geçen yerleşimlerde tespit edilen MÖ VII-V. yüzyıl içlerine kadar izlenebilen ancak MÖ VI. yüzyılda yoğunlaşan seramik buluntular, aynı dönem içerisine tarihlenen pişmiş toprak kaplama levhaları, MÖ VI. yüzyıl ve sonrasina tarihlenen Lydia tipi tümülüslerin yanında ikinci bir tip olarak görülen yerel taş yığma tümülüsler ve tespit edilen Lykia tipi kaya mezarlarıdır. Tüm bu arkeolojik veriler bölgede bu dönemler içerisinde ortak bir kültürün varlığını göstermesi adına oldukça önemlidir.

\section{Kabalis Bölgesi Demir Çağ Gözetleme ve Haberleşme Kaleleri}

Bölgede Özsait (2006, 96, fig.3), Corsten ve Hülden (2012b, 41- 44, fig. 22) ve Dökü ve Baytak'ın (2015, 208- 217) Kabalis Bölgesi'nde yaptığı yüzey araştırmalarında ve Hürmüzlü'nün (Hürmüzlü \& Gerçek 2015, 309- 313) kuzey batı Pisidia'da yaptığı yüzey araştırmalarında, özellikle Roma Dönemi'nde yüksek dağ zirvelerinde basit surlarla çevrelenmiş gözetleme ve
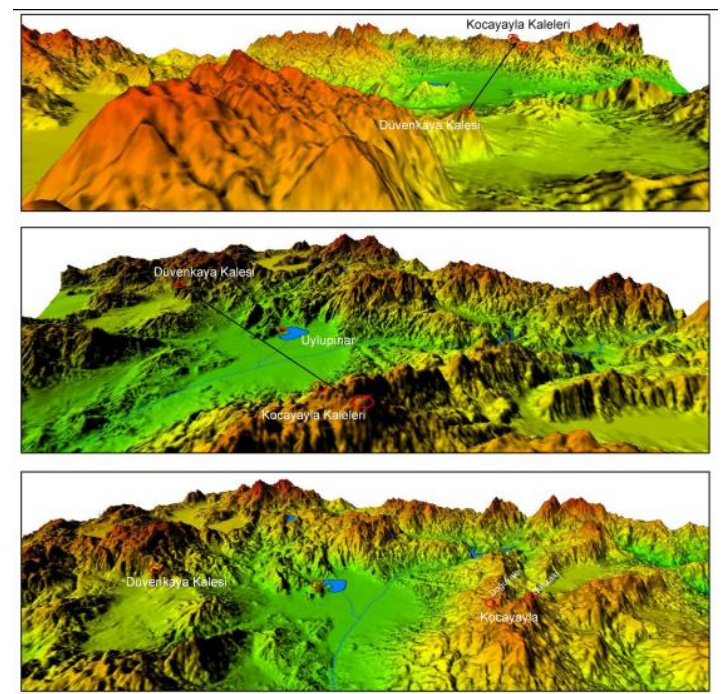
haberleşme kalelerinin varlığından bahsetmişler-

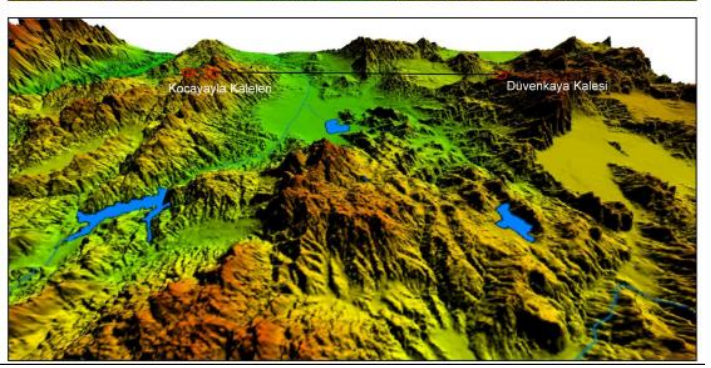

Fig. 15. Demir Çağ Yerleşimleri ve Yerleşimlerle Bağlantılı Gözetleme/Haberleşme Kaleleri Topografik Görünümü (F. Adıgüzel) dir. Roma Dönemi'nde yoğunlaşan bu savunma sistemleri özellikle dağınık yerleşimler arasındaki yol güzergâhlarının kontrolünü sağlayan gözetleme/haberleşme kaleleri olarak da kullanılmıştır.

Yukarıda bahsedilen ve Roma Dönemi yerleşimleriyle aynı coğrafyanın ve hatta aynı höyügün erken yerleşimcileri olan Kaballer, Demir Çağı'nda nasıl bir savunma sistemi kullanmışlardı sorusu önemlidir. Uylupınar (Erken Kibyra) yüzey araştırmaları sırasında Düven Tepe, Kocayayla Doğu ve Batı Kaleleri gibi birçok alan, içlerinde bulunan yoğun Demir Çağ seramiği ile oldukça önemli veriler sunmuştur. Kabalis Bölgesi'nin yüksek yerleşimleri ve etraflarını saran tepeler üzerinde, özellikle Demir Çağı'ndan, geç antikçağa kadar yol ağları ve yerleşimlerle bağlantılı olarak, birbirini gören, etrafları basit moloz taşlarla kuru duvar örgü tekniğinde çevrilmiş duvarlarla izlenen, gözetleme ve haberleşme kalelerinin, farklı dönemlerde aynı işlevde kullanıldıkları görülmüştür (Dökü \& Baytak 2015, 208-217; 2016, 217-240). Tespit edilen bu gözetleme ve haberleşme kalelerin ortak özelliği, duvarlarının içerisinde herhangi bir mimari yapı ile karşılaşılmamış olması yanında, yoğun olarak Demir Çağ seramik buluntusu ile karşılaşılmış olmasıdır. 


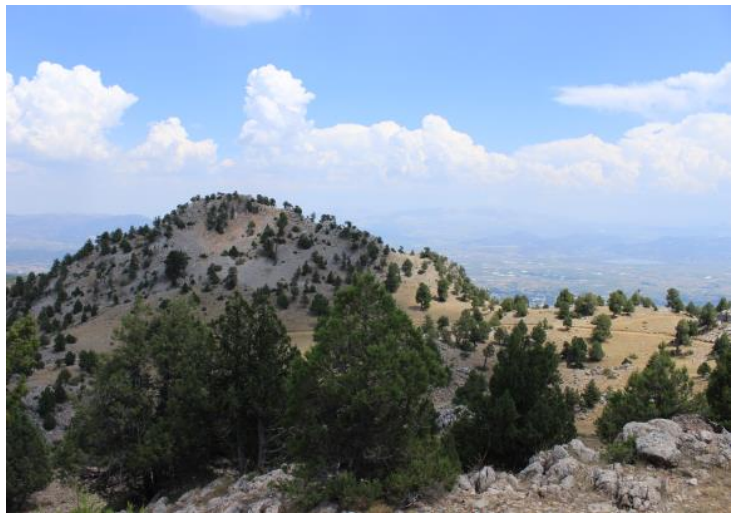

Fig. 16. Kocayayla Doğu Gözetleme ve Haberleşme Kalesi (Kocayaran Tepesi)



Fig. 18a. Kocayayla Doğukale Demir Çağ Seramik Buluntuları

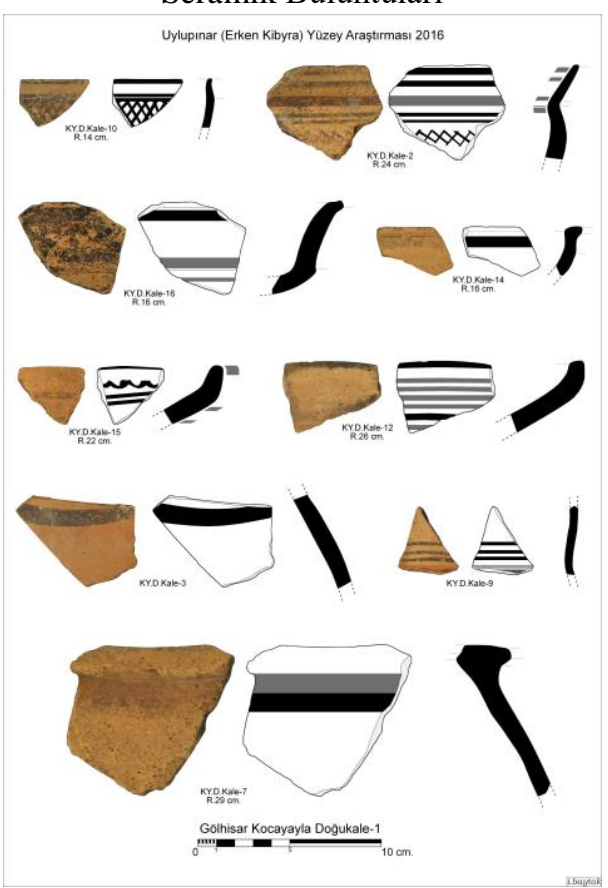

Fig. 18b. Kocayayla Doğukale Demir Çă̆ Seramik Çizimleri - 1

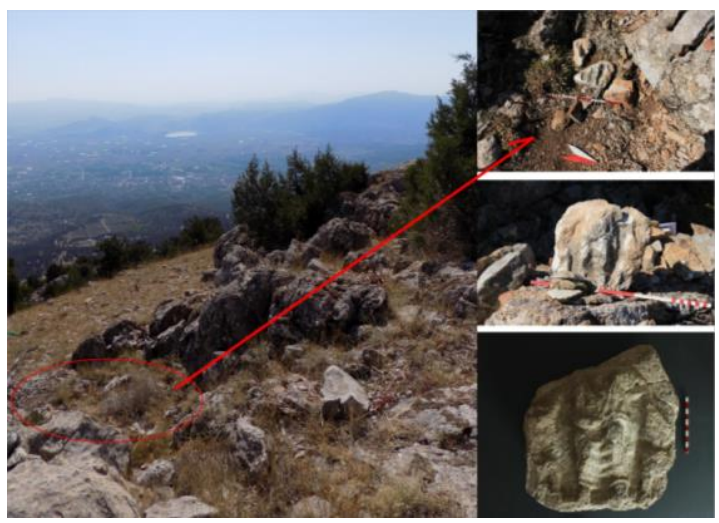

Fig. 17. Kocayayla Doğu Kale Yerleşimi Potnia Theron? Kaya Kabartması

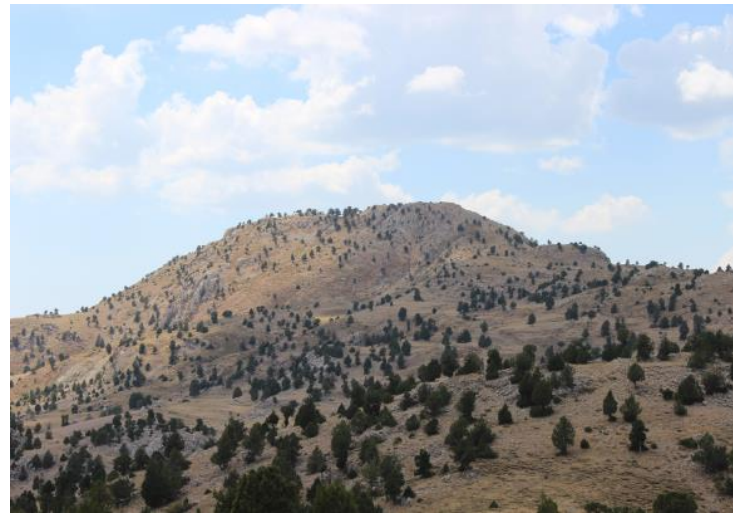

Fig. 19. Kocayayla Batı Kale Yerleşimi (Yalnızca Tepesi)

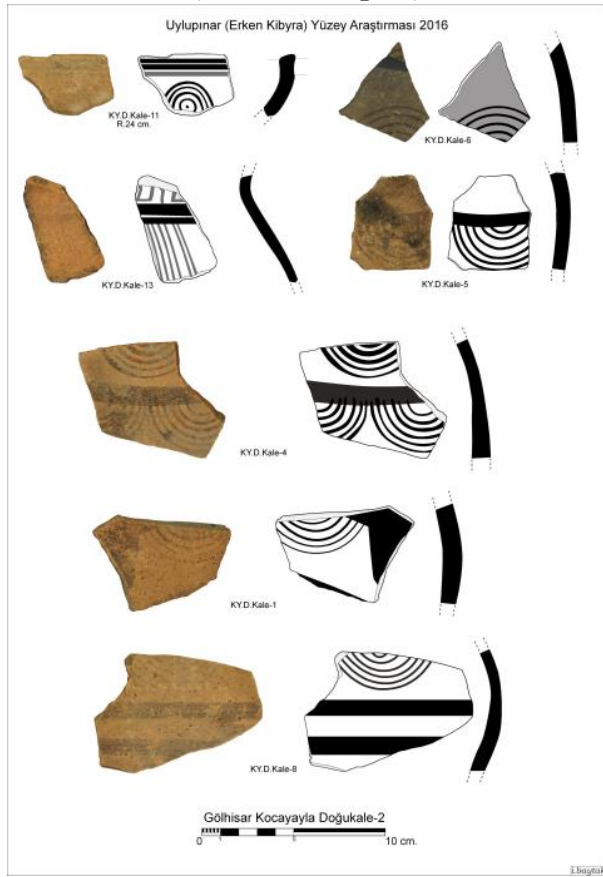

Fig. 18c. Kocayayla Doğukale Demir Çağ Seramik Çizimleri - 2 


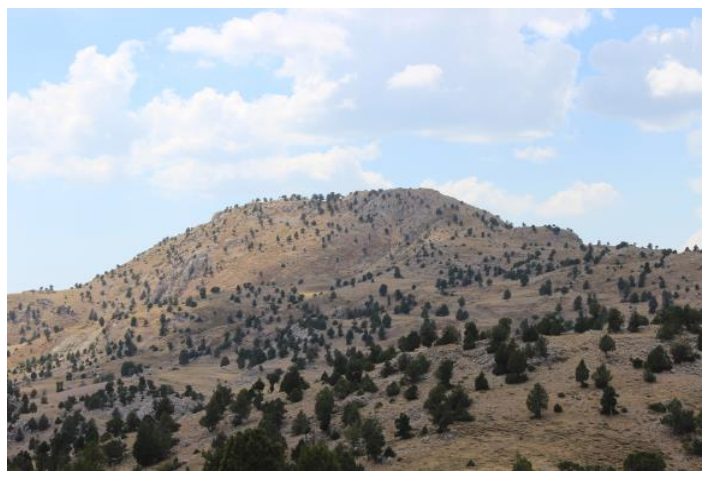

Fig. 19. Kocayayla Batı Kale Yerleşimi (Yalnızca Tepesi)

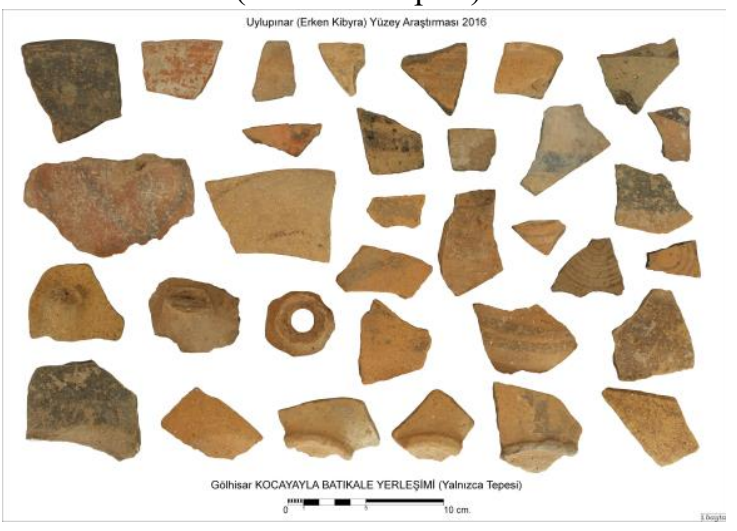

Fig. 21a. Kocayayla Batıkale Demir Çağ Seramik Buluntuları

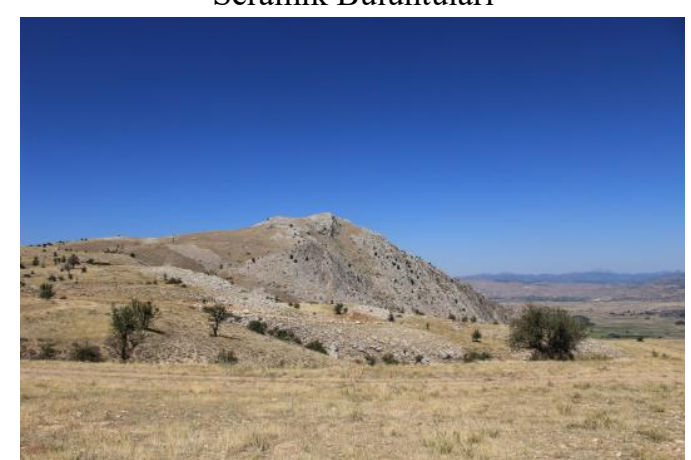

Fig. 22. Düvenkaya Gözetleme ve Haberleşme Kalesi (Başpınar'dan)

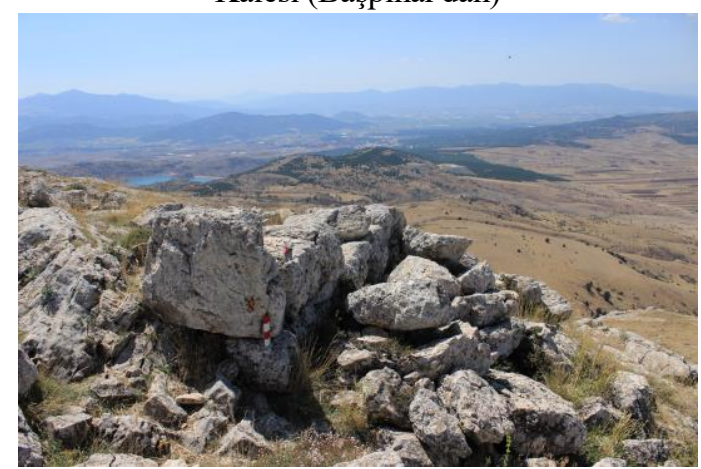

Fig. 23. Düvenkaya Gözetleme ve Haberleşme Kalesi Sur İzleri

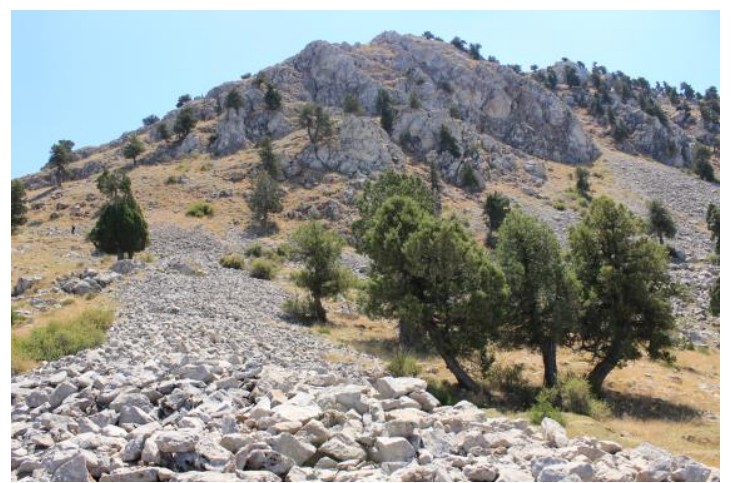

Fig. 20. Kocayayla Batı Kale Yerleşimi (Yalnızca Tepesi)

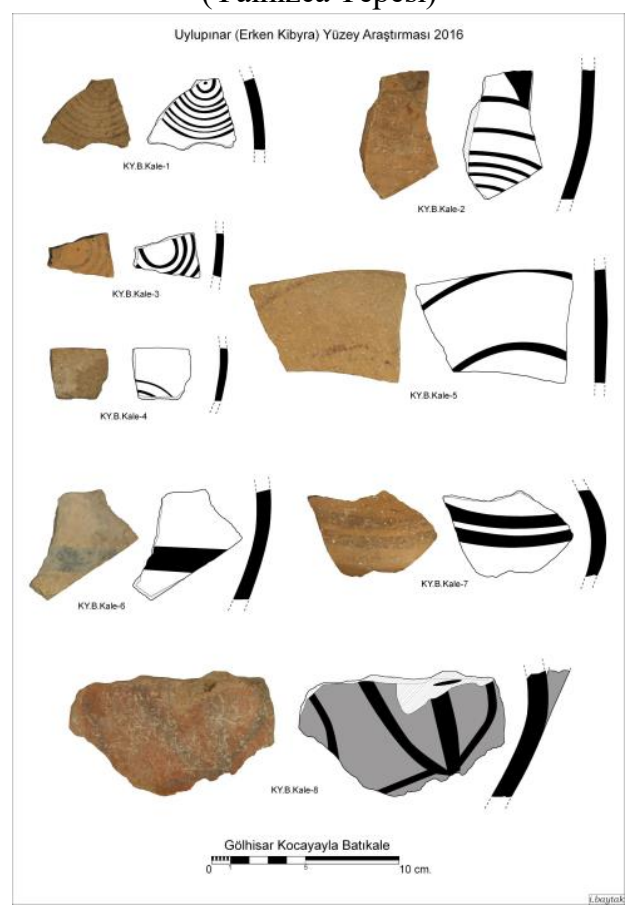

Fig. 21b. Kocayayla Batıkale Demir Çağ Seramik Çizimleri

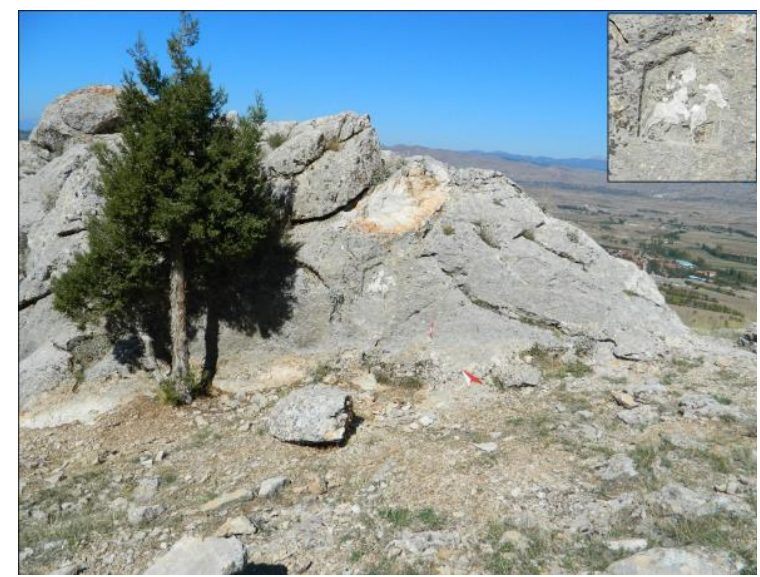

Fig. 24. Düvenkaya Kakasbos Kabartmaları 


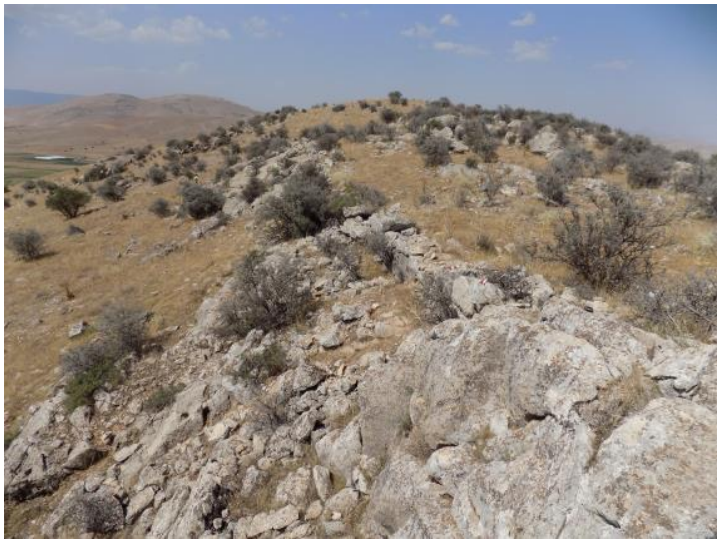

Fig. 25. Hasanpaşa Aktepe Gözetleme/Haberleşme Kalesi

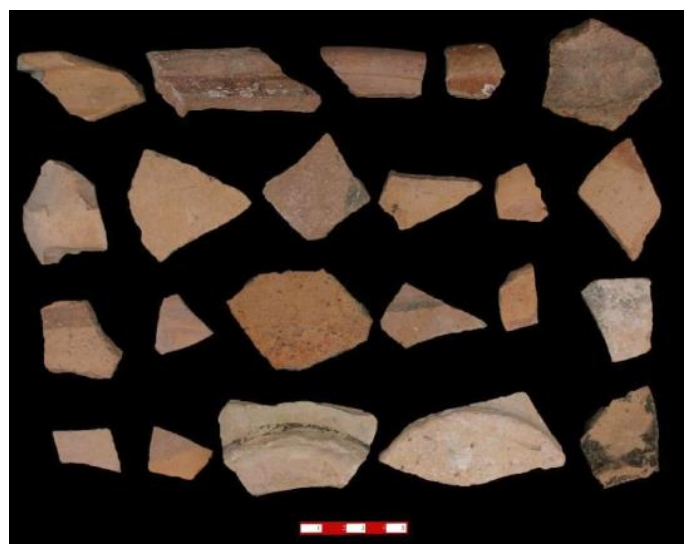

Fig. 26. Hasanpaşa Aktepe Kale Yerleşimi Demir Çağ Seramik Buluntuları

Dökü ve Baytak'ın (2016, 217-240) Uylupınar (Erken Kibyra) 2015-2016 yılları arası yüzey araştırmalarında, Tefenni Karamusa Höyük'ün doğusunda yükselen tepe zirvesinde bir adet ve Kibyra'nın batısında Kocayayla olarak adlandırılan yüksek yaylada, doğu ve batı yönde iki adet gözetleme/haberleşme kalesi tespit edilmiştir. Bu kaleleri diğer kalelerden ayıran ise moloz taş, kuru duvar örgü duvarları her ne kadar günümüzde tepenin yamacına doğru akmış olsa da, içerisinde yoğun ve baskın olarak Demir Çağı seramiklerinin varlığıdır. Bu seramikler aşağıda da ayrıntılı olarak anlatılacağı üzere, Uylupınar Demir Çağı seramik buluntu repertuvarı ile benzer ve çağdaştır. Kocayayla Doğu kale olarak Adlandırılan Kocayaran Tepesi üzerindeki haberleşme ve gözetleme kalesi, Uylupınar yerleşimini ve Gölhisar ovasına hakim bir yapıdadır. Batı kale olarak adlandırılan Yanlızca isimli tepenin üzerinde yer alan haberleşme ve gözetleme kalesi ise, Acıpayam ovasını kontrol eder (Figs. 2, 15). Uylupınar yerleşiminin kuzey batısında bulunan Karamusa Höyük üzerinde yer alan ve Dökü-Baytak tarafından 2015 yılı çalışmalarında tespit edilen Düven Kayası tepesinde yer alan gözetleme kalesi de aynı tiptedir. Bu alanda izlenen seramikler yine Orta Demi Çağ Sonu, Geç Demir Çă̆ ve Roma Dönemi seramikleridir. $\mathrm{Bu}$ haberleşme ve gözetleme kalesi de bir taraftan Uylupınar yerleşimini görürken, batıda bu gün Tefenni ovasında yer alan Karamusa Höyük, Manca ve Höyük Höyük gibi yoğun Demirçağ malzemesinin izlendiği yerleşimleri kontrol eder. Dolayısıyla daha önce bölgede tespit edilen Hellenistik ve Roma dönemlerine tarihlendirilen kalelerin öncülü Demir Çağında, yukarıda bahsedilen yerleşimlerin korunması için yapılmış, haberleşme ve gözetleme amacıyla kullanılmışlardır.

Kocayayla Doğu Haberleşme ve Gözetleme Kalesi (Kocayaran Tepesi): Kocayayla olarak bilinen alanda zirve ve eteklerinde yapılan incelemeler sonucunda kuzey-güney (370 m) uzantılı ve doğu-batı $(260 \mathrm{~m})$ yamaçlarında moloz taşlarla düzenlenmiş kuru duvar sur izleri mevcut bir kale yerleşimi tespit edilmiştir (Figs. 2, 16). Alanda yapılan incelemelerde Son Tunç Çağ 1 Demir Çağı - Roma Dönemi ve Geç Antik Çağ seramikleri görülmüştür. Kalenin üst kısmında 9.50 x 8.90 m ölçülerinde doğu-batı uzantılı 2 dikdörtgen yapının birleşiminden oluşan ve doğu uçlarının apsis şeklinde olduğu bir mekan görülmüştür. $1.50 \mathrm{~m}$ dış duvar kalınlığı olan yapının iç kısmı da 5.65 m'lik bir uzunluğa sahiptir. Yapı $1,20 \mathrm{~m}$ iç duvar ile ikiye ayrılmış $2 \mathrm{~m}$ ve 2,5 $\mathrm{m}$ büyüklüğünde iki dikdörtgen oda halini almıştır. $2 \mathrm{~m}$ yarıçaplı iki apsisli iki oda, doğuya bakar durumdadır. Olasılıkla bu apsisli yapının, alanda bulunan Geç Antik Çağ seramiklerine dayanarak, bir şapel olarak kullanılmış olduğu düşündürmektedir. Bu alanın kutsal bir yer olarak kullanıldığını gösteren en önemli iz ise, şapelden daha erken bir tarihte, Roma Döneminden olduğu düşünülen olasılıkla kalenin içerisindeki yüksek kayalıktan ters olarak 
düşerek parçalanmış ve araştırmalarımız sırasında bulunmuş olan bir kaya kabartmasıdır. Bulunan parçalar birleştirildiğinde, $20 \mathrm{~cm}$ yüksekliğinde her iki yanında aslanların olduğu baş1 olmayan bir adet kadın figürlü kabartma olduğu tespit edilmiştir. Bu büyük olasılıkla bir Potnia Theron - Artemis Lagbene kabartması olup Ş. Özüdoğru tarafindan yayına hazırlanmaktadır. Ancak bu kabartma Kocayaran tepesinin Roma Dönemi'nde de gözetleme ve haberleşme işlevini korurken, aynı zamanda bir açık hava tapınım alanı olarak da kullanılmış olduğunu göstermektedir (Fig. 17). Ayrıca bu kalede yoğun olarak karşılaşılan Demir Çağ Seramikleri, (Fig. 18 a-c) Uylupınar Yerleşimi seramikleri ile benzerlikten öte aynıdır (Fig. 3).

Aynı zirvede bu mekanın yaklaşık $6 \mathrm{~m}$ güneyinde $5.20 \mathrm{~m}$ ölçülerinde çevre örgüsü olan 2 m’lik kaçak kazı çukuru belirgin taş yığma tümülüs görülmüştür (Dökü \& Baytak 2018). Ancak bu taş yığma tümülüsün içinden dönemini belirleyecek arkeolojik materyalle ulaşılmamıştır. Kalenin yamaçlarında da yine aynı şekilde dört taş yığma Tümülüs daha izlenmiştir. Bunlardan biri hemen kalenin güney batı yamacında diğer üçü ise yoğun kaçak kazı ile tahrip edilmiş halde kalenin kuzeyinde tespit edilmiştir. Koca Yaylanın ortasında oluşan bu alana, karstik göl nedeniyle günümüzde Göl Mezarlığ isminin verilmiş olması da dikkate değerdir.

Kocayayla Batı Gözetleme ve Haberleşme Kalesi (Yalnızca Tepesi): Kocayayla Doğu Kalenin tam karşısına batı yönüne doğru $2.4 \mathrm{~km}$ mesafede Çameli Yayla yolu üzerinde oldukça yüksek ve hakim bir tepede 600 x 950 m ölçülerinde kuzey-güney doğrultuda uzanan $2023 \mathrm{~m}$ yüksekliğinde bir dağ yükseltisidir. Bu yükseltinin doğu ve batı eteklerinde moloz taşlardan oluşan kuru duvar sur yıkıntı izleri belirgindir. Alanda zirve ve doğu eteklerinde Demir Çağ (Fig. 21a, b) - Roma Dönemi - Geç Antik Çağ malzemeleri yoğun olarak izlenmektedir. 3-5 m çaplarındaki bu kaçak kazı alanlarında bölgeden çokça bildiğimiz taş yığma tümülüs izleri görülmektedir. Yine aynı alanda zirvenin güney kısmında 6.10 x 14.20 m ölçülerinde dikdörtgen planlı bir mekan yapısı görülmüştür. Batı kanatta zirveden aşağıya doğru $110 \mathrm{~m}$ kadar dik inen $1.60 \mathrm{~m}$ kalınlığında $1988 \mathrm{~m}$ kodlarında duvar izleri oldukça belirgin görünmektedir (Dökü \& Baytak 2018) (Figs. 2, 19, 20).

Bu kale gözetleme ve haberleşme kalesi doğuya göre daha büyük bir alanı kaplar içerisinde belli belirsiz duvar izleri ve çatı kiremitleri de izlense de dönemlerini tespit etmek oldukça güçtür. Moloz taş ve kuru duvar örgü savunma duvarı izleri kısmen izlenirken, bu duvarların eteklere doğru aktığı tespit edilmiştir. Alanda görülen seramik buluntu, buranın Demir Çağından Roma Dönemi ve hatta Geç Antik Çağ'da da aynı işlevde kullanıldığını göstermektedir. Yalnızca tepesi zirvesinde bulunan gözetleme ve haberleşme kalesi batı yönde tüm Acıpayam Ovasını görebiliyorken güney-doğu yönde ise Gölhisar-Karamanl1-Tefenni'ye kadar geniş bir alanı kontrol etmektedir.

Karamusa Höyük ve Düvenkayası/Düven Tepesi Gözetleme ve Haberleşme Kalesi: Başpınar ve Karamusa Köyleri arazisi içerisinde yer alan Karamusa'nın $1 \mathrm{~km}$ kadar güneybatısında yüksekçe bir zirve $(1500 \mathrm{~m}$ ) yer almaktadır (Figs. 2, 22). Zirvede oldukça belirgin duvar izleri yerleşim ve nekropol izleri görülmektedir. Yine bu alanlarda özellikle mezar çukurlarında yapılan çalışmalarda Demir Çağ seramiklerine rastlanılmıştır. Zirvenin alt yükseltilerinde batı kısımda kayalığın kuzey kesiminde (1425 m) monoblok bir kayalığın güney kesimine işlenmiş biri tahrip edilmiş 4 adet Kakasbos kabartması yer almaktadır (Figs. 24). Bu kale, Uylupınar Yerleşiminin kuzey batısında yer alan ve bölgede Uylupınar Yerleşiminden sonra en önemli Demir Çağ yerleşimlerinden biri olan Karamusa Höyük'ün hemen doğusunda yükselen tepenin zirvesinde tespit edilmiştir (Dökü \& Baytak 2016, 230-231).

Kuzey güney doğrultulu $1 \mathrm{~m}$ mevcut yükseklikte ve $5.50 \mathrm{~m}$ mevcut uzunluğu bulunan 80 $\mathrm{cm}$ kalınlığında kayaların arası moloz taş ve kuru duvar örme savunma duvarı ile alan 
çevrelenmiştir (Fig. 23). Ayrıca aynı Kocayayla Doğu kale gibi Roma Dönemi'nde bir açık hava tapınımı yapıldığını anlatan Kakasbos kaya kabartmalarının varlığı da önemlidir. Bu alan bir taraftan Uylupınar Yerleşimini görürken diğer yandan da tüm Tefenni ovasına hakim yapısıyla bu alandaki Demir Çağ Yerleşimlerini izlemektedir.

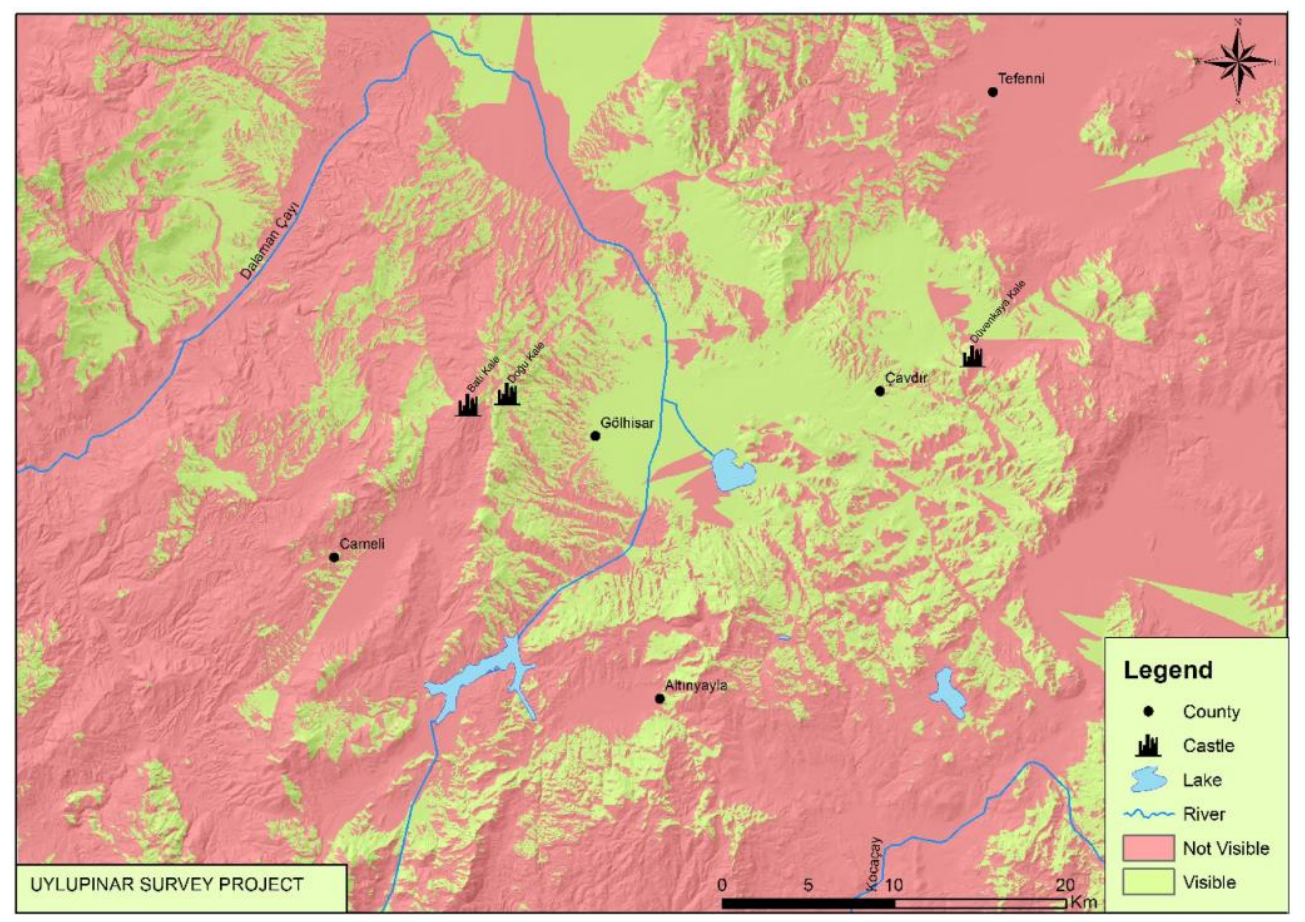

Fig. 27. Kalelerin Görünürlük Analizi (F. Adıgüzel)

Hasanpaşa Aktepe Kale Yerleşimi: Tefenni sınırları içerisinde Hasanpaşa Ovası'nın bitiminde Manca ve Hasanpaşa kaya mezarlarının orta istikametinde yer alan sur kalıntıları ve yerleşim izleri mevcut oldukça belirgin bir kale izlenmiştir (Fig. 25). Kuzeyinde Hüyük Höyük, doğusunda Manca Höyük, batısında Hasanpaşa Höyük ve güneyinde Yarım Höyük yer almakta olup oldukça stratejik ve önemli bir yerdir. Tescili yapılmış olan Aktepe ve çevresinde yapılan araştırmalar sonucunda MÖ I. bin Demir Çağ boyalı seramiklerinin yanı sıra Hellenistik ve Roma Dönemi'nden de kültür izlerine rastlanılmıştır (Dökü \& Baytak, 2015, 208-217; 2016, 230) (Fig. 26).

Yayla Kayasi/Kalesi Aliyürek Tepesi Kale Yerleşimi: Tefenni İlçesi sınırlarında, 18 km kadar batısında, Sazak Köyü'nün 4 km güneybatısında, yer alan Yayla Kalesi ya da Yayla Kayası'nda Özsait'in çalışmalarında, surları olan yoğun halde yapı tuğlaları ve maden cürufları bulunan bir Demir Çağı kalesi yer almaktadır. Demir Çağı buluntularının yanı sıra alanda yoğun halde yapı tuğlaları ve maden cürufları bulunmaktadır (Dökü \& Baytak, 2015, 208-217; 2016, 230).

Yukarıda bahsedilen Demir Çağ gözetleme ve haberleşme kalelerinin seramiklerinin değerlendirilmesi ayrı bir çalışma halinde değerlendirilecektir. Bu alanlarda görülen seramik buluntular ile kalelerin hemen alt eteklerinde izlenen yerleşimlerde bulunan seramik repertuvarlarının farklı olmaması ve dönemlerinin örtüşmesi şaşırtıcı değildir.

\section{Kabalis Bölgesi Demir Çağ Gözetleme ve Haberleşme Kaleleri Görünürlük Analizi}

Çalışma alanında yer alan 3 adet kalenin yerleri GPS ile koordinat değerleri belirlenerek ve ArcGIS 10.4 programı ile (Görünürlük) Viewshed analizi gerçekleştirilmiştir. Harita altlığı olarak Sayısal Yükseklik Modeli (SYM) kullanılmış yani yükselti değerleri saptanarak analiz yapılmış- 
tır. Kalelerden tüm çalışma alanları taranması için görüş açısı $360^{\circ}$ olarak kabul edilmiştir ve çalışma alanının kalelerden görünen ve görünmeyen yerleri tespit edilmiştir (Fig. 27). Haritada görüldüğü üzere sarı ile gösterilen alanların tümü bu gözetlene ve haberleşme kalelerinin gözetimi altındadır ve neredeyse tüm Gölhisar ve Tefenni ovası kontrol altındadır. (Görünürlük analizi Uylupınar Erken Kibyra Bilim Heyeti Üyesi, Öğr. Gör. Fatih Adıgüzel tarafından yapılmıştır).

\section{Sonuç ve Değerlendirme}

Uylupınar (Erken Kibyra) yüzey araştırmalarında elde edilen ve yukarıda ayrıntısı ile anlatılan Demir Çağ yerleşimleri ve bu yerleşimlerle bağlantılı gözetleme/haberleşme kaleleri, bölgede daha önce bilmediğimiz bir yerleşim ve koruma ağını anlatmaktadır. Son Kalkolitik Dönem ile başlayan yerleşimlerin büyük çoğunluğunda, Erken ve Orta Tunç Çağı izlenilebiliyorken, az sayıda yerleşimde Geç Tunç Çağı ile karşılaşılmıştır. Buna karşın aynı yerleşimlerin üstünde Erken Demir Çağ'a dair veriler neredeyse yoktur. Özellikle höyüklerde yoğun olarak Orta Tunç ve Erken Demir Çağ'a ait izler görülmezken Orta Demir Çağı sonu ve Geç Demir Çağ başlarına tarihlenebilecek seramik buluntuları yoğunlaşır. $\mathrm{Bu}$ yerleşimlerin hemen üstünde, Klasik Dönem ve Erken Hellenistik Dönem'e kadar özellikle ithal malzeme ile çok az sayıda karşılaş1lırken, Geç Hellenistik Dönem buluntuları ise bütün yerleşimlerde izlenmez. Buna karşın en yoğun buluntu grubunu ise Roma ve Geç Antik Çağ izleri oluşturur.

Yukarıda bahsedilen gözetleme ve haberleşme kaleleri ise buluntulardan da anlaşlacağ üzere, Demir Çağı'ndan, Roma Dönemi'ne kadar, aynı coğrafyada, şekilde yerleşen ve aynı yolları kullanan, hatta aynı güvenlik sorunlarına benzer çözümler sunan bir biçimde kullanılmışlardır. Bu gözetleme ve haberleşme kaleleri bölgede coğrafyanın belirlediği ve geçen dönemlerin pek müdahil olamadıkları yolları ve yerleşimleri koruyan dağ zirvelerinde birbirlerini görecek şekilde konuşlandırılmış, basit moloz yüksek olmayan duvarlarla çevrili, içerisinde kalıcı bir mimarinin izlenmediği ve olasılıkla ahşap mekânlardan oluşan savunma sistemleridir. $\mathrm{Bu}$ yapılar ve gözetim altında tuttukları alanlarda yapılacak araştırmalar, Kabalis Bölgesi Demir Çağı'nı daha iyi anlayabilmemiz için önemlidir. 


\section{KAYNAKÇA}

\section{Antik Kaynaklar}

Hdt. (= Herodotos, Historiai) Kullanılan Metin ve Çeviri: Herodot Tarihi. Çev. M. Ökmen. İstanbul 1991.

Ksen. (= Ksenophon, Kyrou Anabasis) Kullanılan Metin ve Çeviri: Ksenophon, Onbinlerin Dönüşü. Çev. T. Gökçöl. İstanbul 1984.

Ptol. Geogr. (= Ptolemaios, Geographika) Kullanılan Metin ve Çeviri: (Claudius Ptolemaeus, griechischer Geograph, um 100 n. Chr.-um 160 n. Chr.). Ed. C. F. A. Nobbe, Claudii Ptolemaei geographia. Vol. 1-2. Leipzig 1843-1845 (repr. Hildesheim 1966).

Step Byz. (= Stephanus Byzantinus, Ethnica) Kullanılan Metin ve Çeviri: Stephanus Byzantinus, Ethnica, Quem Primus Thomas de Pinedo Lusitanus, Amstelodami (Typis Jacobi de Jonge) 1778.

Strab. (= Strabon, Geographika) Kullanılan Metin ve Ceviri: (Strabon, griechischer Geograph, um 63 v. Chr.-nach 23. n. Chr.): Strabons Geographica.Herausgegeben von Stefan Radt. 10 Bände, Göttingen 2002-2011.

\section{Modern Literatür}

Akarca A. (1972). Şehir ve Savunması: Yunan Arkeolojisinin Ana Çizgileri-I. Ankara 1972.

Akurgal E. (1996). "Batı Anadolu'da Konut, Yerleşme ve Kent Planlaması (MÖ. 3000-30)". Ed. Y. Sey, Tarihten Günümüze Anadolu'da Konut ve Yerleşme (1996) 122-43.

Baytak İ. (2014). Kabalis (Kibyratis) Bölgesi Tarihi Coğrafyası ve Çağlar Boyu Yerleşim ModelleriUrbanizasyon. Yayımlanmamış Doktora Tezi. Konya 2014.

Butler H. C. (1922). Sardis, Volume I. The Excavations Part 1: 1910-1914. Leyden 1922.

Coldstream J. N. (2009). Greek Geometric Pottery. A Survey of Ten Local Styles and Their Chronology. 2009.

Corsten Th. \& Hülden O. (2011). "Kibyratis Araştırmaları 2010". Anmed 9 (2011) 180-183.

Corsten Th. \& Hülden O. (2012a). "Kibyratis Araştırmaları". Anmed 10 (2012) 174-177.

Corsten Th. \& Hülden O. (2012b). "Zwischen den Kulturen. Feldforschungen in der Kibyratis. Bericht zu den Kampagnen 2008-2011”. IstMitt 62 (2012) 7-117.

Coulton J. J. (2012). The Balboura Survey and Settlement in Highland Southwest Anatolia Vol. 1: Balboura and the History of Highland Settlement; Vol. 2: The Balboura Survey: Detailed Studies and Catalogues Ankara 2012.

Cummer W. W. (1970). "Phrygian Roof Tiles in the Burdur Museum". Anatolia 14 (1970) 29-55.

Çankaya A. (2014). "Bademli-Yuvalak Tümülüsleri Işı̆̆ında Pisidia Bölgesi’nin Hellenistik Dönem Öncesi Mezar Mimarisi”. Eds. B. Hürmüzlü, M. Fırat \& A. Gerçek, Pisidia Sempozyumu: Pisidia Araştırmaları I (2014) 246-56.

Çokay-Kepçe S. (2009). “The Pottery from Burdur Uylupınar Necropolis”. Adalya 12 (2009) 29-76.

Dökü F. E. \& Baytak İ. (2014). "Uylupınar (Erken Kibyra) Yerleşimi Yüzey Araştırması”. Eds. B. Hürmüzlü, M. Frrat \& A. Gerçek, Pisidia Sempozyumu: Pisidia Araştırmaları I (2014) 71-89.

Dökü F. E. \& Baytak İ. (2015). "2014 Yılı Uylupınar(Erken Kibyra) Yerleşimi Yüzey Araştırması”. Anmed 13 (2015) 208-217.

Dökü F. E. \& Baytak İ. (2016). "Uylupınar (Erken Kibyra) Yerleşimi 2013-2014 Yılları Yüzey Araştırmaları". AST XXXIII/1 (2016) 217-240.

Dökü F. E. \& Baytak İ. (2017). "Korkuteli Karabayır Taş Yığma Tümülüsleri Işı̆̆ında Demir Çağ Kabalis ve Milyas İlişkileri”. Cedrus V (2017) 11-19.

Dökü F. E. \& Baytak İ. (2018).“2016 Yı1ı Uylupınar (Erken Kibyra) Yerleşimi Yüzey Araştırması”. Anmed 15 (baskida).

Dökü F. E. (2013). "Uylupınar Yerleşmesi (Erken Kibyra) ve Çevresi Yüzey Araştırması 2012”. Anmed 11 (2013) 239-249.

Dökü F. E. (2014). "2013 Yılı Uylupınar (Erken Kibyra) Yerleşimi Yüzey Araştırması”. Anmed 12 (2014) 230-236. 
Dökü F. E. (2015). “Manca ve Hasanpaşa'daki Yeni Bulgular Işı̆̆ında Kabalis Ölü Gömme Geleneklerinin Yeniden Değerlendirilmesi”. Adalya 18 (2015) 73-100.

Dörtlük K. (1975). “1975 Uylupınar Kazı Raporu”. TAD 24/II (1975) 9-32.

Dörtlük K. (1988). “Elmalı Bayındır Tümülüsleri Kurtarma Kazısı”. KST X/1 (1988) 171-174.

Gay K. A. \& Corsten Th. (2006). "Lycian Tombs in the Kibyratis and the Extent of Lycian Culture". Anatolian Studies 56 (2006) 47-60.

Greenewalt Jr. C. H. (1968). Lydian Pottery of the Sixth Century BC. The Lydion and Marbled Ware. Philadelphia 1968.

Hürmüzlü B. \& Gerçek A. (2015). "Pisidia'da Yeni Bir Kale Yerleşmesi”. Eds. C. Şimşek, B. Duman \& E. Konakçı, Mustafa Büyükkolancı'ya Armağan (2015) 309-313.

Işık F. (2010). “Anadolu-Lykia Uygarlığı, Lykia'nın 'Hellenleşmesi’ Görüşüne Eleştirel Bir Yaklaşım”. Anatolia 36 (2010) 65-125.

Kahya T. \& Ekinci H. A. (2015). "Düver- Yarım Ada'da Keşfedilen Ana Tanrıça Tapınakları". Adalya 18 (2015) 45-72.

Kahya T. (2011). "Düver Yerleşim Tarihi Araştırmaları 2010”. Anmed 9 (2011) 219-223.

Kahya T. (2012a). "Düver Yerleşim tarihi ve Araştırmaları 2011”. Anmed 10 (2012) 148-153.

Kahya T. (2012b). "The Rock Tomb on The Düver Peninsula: An Early Example from Pisidia and Remarks on Cultural Interaction". Adalya 15 (2012) 13-32.

Kahya T. (2012c). "Pisidia Arkaik Dönem Pişmiş Toprak Çatı Elemanları Üzerine Bazı Gözlemler”. Eds. K. Dörtlük, T. Kahya, R. Boyraz Seyhan \& T. Ertekin, Uluslararası Genç Bilimciler Buluşması-I: Anadolu Akdenizi Sempozyum Bildirileri/International Young Scholars Conference-I: Mediterranean Anatolia, Symposium Proceedings (2012) 177-194.

Kaşka M. (2014). “Uylupınar Yüzey Araştırmasında Ele Geçen Arkaik Dönem Seramikler”. Eds. B. Hürmüzlü, M. Fırat \& A. Gerçek, Pisidia Sempozyumu: Pisidia Araştırmaları I ( 2014) 285-293.

Lloyd S. \& Mellaart J. (1962) Beycesultan I, The Chalcolithic and Early Bronze Age Levels. London 1962.

Mellaart J. (1965). Early Civilisations of the Near East. London 1965.

Milner N. P. \& Hall A. S. (1998). An Epigraphical Survey in the Kibyra-Olbasa Region, Conducted, By: A.S. Hall, Regional Epigraphic Catalogues of Asia Minor-III, BIAA Monograph 24. Ankara 1998.

Özsait M. (1977). "Pisidya Bölgesinde Yeni Prehistorik İskan Yerleri I: Kuruçay, Çiğirkankaya, Çallıca Yağlıyurt Yerleşmeleri”. AnAr 4/5 (1976/1977) (1977) 71-95.

Özsait M. (1979). “Burdur Çevresinde Yeni Prehistorik Yerleşmeler”. TTKong.-8 (1979) 101-106.

Özsait M. (1980). İlkçă̆ Tarihinde Pisidya, Başlangıçtan Büyük İskender Devrinin Sonuna Kadar. İstanbul 1980.

Özsait M. (1983). "Pisidya Bölgesinde Yeni Prehistorik İskân Yerleri II (19 Levha ile birlikte)”. AnAr 9 (1983) 133-148.

Özsait M. (1984). “1982 Yılı Burdur Çevresi Prehistorik Araştırmaları”. AST I (1984) 7-12.

Özsait M. (1985). Hellenistik ve Roma Devrinde Pisidya Tarihi. İstanbul 1985.

Özsait M. (1986a). "Burdur Çevresinde Prehistorik Araştırmalar”. TTKong.-9 (1986) 63-66.

Özsait M. (1986b). “Pisidya Bölgesinde Yeni Prehistorik İskân Yerleri III”. AnAr 10 (1986) 73-87.

Özsait M. (1989). "Pisidya Bölgesinde Yeni Prehistorik İskân Yerleri-IV(23 Levha ile birlikte)". AnAr 11 (1989) $1-21$.

Özsait M. (1991). “1989 Yılı Gölhisar ve Çevresi Tarih Öncesi Araştırmaları”. AST VIII (1991) 35-44.

Özsait M. (2006). "Burdur İli 2005 Yılı Yüzey Araştırmaları”. Anmed 4 (2016) 93-98.

Özsait M. (2007). “Burdur İli 2005 Yılı Yüzey Araştırmaları”. AST XXIV/2 (2007) 463-478.

Özsait M. (2008). “Burdur ve Isparta Yüzey Araştırmaları 2006”. AST XXV/2 (2008) 307-322.

Özsait M., Labarre G. \& Özsait N. (2005). "Researches dans le village de Kağılcık(Piside)-Le sanctuaire rupestre et les inscriptions". Adalya 8 (2005) 167-89.

Özsait M., Özsait N. \& Baytak İ. (2010). “2008 Yılı Isparta ve Burdur Yüzey Araştırmaları”. AST 
XXVII/2 (2010) 419-438.

Özüdoğru Ş. \& Dökü F. E. (2010). "Kibyra 2009 Yılı Çalışmaları”. Anmed 8 (2010) 37-45.

Özüdoğru Ş. (2009). "Uylupınar Göl Adası Yerleşmesi Arkeolojik Veriler ve Kibyra İçin Önemi”. Eds. K. Dörtlük, T. Kahya, R. Boyraz Seyhan \&T. Ertekin, Uluslararası Genç Bilimciler Buluşması-I: Anadolu Akdenizi Sempozyum Bildirileri/International Young Scholars Conference-I: Mediterranean Anatolia, Symposium Proceedings (2009).

Özüdoğru Ş. (2014).“Kibyra’dan Hellenistik Dönem’e Ait Yeni Bulgular Üzerine Değerlendirmeler”. Cedrus II (2014) 171-188.

Polat-Becks B. A. (2014). "Uylupınar örneğinde Bir Model olarak Göl Adası Yerleşimi ve Arazi Kullanımı”. Eds. B. Hürmüzlü, M. Fırat \& A. Gerçek, Pisidia Sempozyumu: Pisidia Araştırmaları I (2014) 90-107. 